\title{
Związki kulturowe monasteru supraskiego z kulturą serbską w XVI wieku
}

\author{
Antoni Mironowicz \\ Uniwersytet w Białymstoku \\ Polska \\ amir@uwb.edu.pl
}

\begin{abstract}
Antoni Mironowicz, Cultural relations of the Suprasl monastery with Serbian culture in the sixteenth century, Elpis, 19 2017: 149-168.
Abstract: In the 16-th century the monastery of Suprasl was the second monastic center of the Orthodox Church in the Great Duchy of Lithuania after the Kiev-Caves Monastery. In the history of the Byelorussian culture the monastery in Suprasl occupies unique place. The best achievements of many branches of culture have been concentrated in it. They mirror close contacts with the religious and cultural heritage of other Slavonic nations. The monastery became a place of the reciprocal permeating of various religious trends. Also, here, many national cultures influenced each other. An example of this reciprocal permeating of cultures was the architecture and interior decorations of the Annunciation monastery church. The uniqueness of the architecture of this building consists in the mixing of the Gothic and Byzantine styles. The direct connections of Suprasl with Byzantine and Serbian culture may be proved by the monumental frescos in the Annunciation Church. They were painted by a group of painters under the supervision of Nektorius the Serb (Serb Nekhtarioosh). These frescos were a testimony to dogmatic Orthodoxy. The monastery of Suprasl was visited by many outstanding writers, religious leaders and political notables. This monastery was also visited by the Patriarch of Constantinople - Jeremiash II, the Serbian and Bulgarian patriarch - Gabriel, and many other Church dignitaries from Balkans. In the 16-th century, the monastery of Suprasl became a major ecclesiastical center of all the Slavic nations. The monastery while being the major center of Orthodox theological thought, still remained open for new trends in philosophical thought. During the 16-th century the monastery of Suprasl was in close relationship with Bulgaria, Serbia, The Great Duchy of Moscow and Holy Athos Mount. This found its reflection in sacral art, publishing and literature.
\end{abstract}

\begin{abstract}
Streszczenie: Monaster supraski, w XVI wieku był drugim po Ławrze Kijowsko-Peczerskiej prawosławnych ośrodków zakonnych na terenie Wielkiego Księstwa Litewskiego. Monaster supraski zajmuje niekwestionowane miejsce w historii Kościoła prawosławnego, regionu i kultury wielu narodów. Ten najbardziej wysunięty na zachód prawosławny ośrodek klasztorny przekształcił się w drugiej połowie XVI w. w centrum kulturowe o znaczeniu ogólnosłowiańskim. Trudno bowiem wskazać inny ośrodek, w którym w takim zakresie skoncentrowane zostały najlepsze osiągnięcia różnych dziedzin kultury i w którym tak intensywnie przejawiały się kontakty z kulturą innych narodów słowiańskich, a najgłębsze i stare tradycje weszły organicznie w życie następnych wieków. Bezpośrednie związki Supraśla z kulturą serbską znajdują potwierdzenie w wystroju wnętrza cerkwi Zwiastowania NMP. Najważniejszą inwestycją klasztorną była wspomniana wyżej cerkiew Zwiastowania NMP. Wystrój wewnętrzny świątyni wskazuje na silne wpływy kulturowe bizantyjsko-ruskie na zachodnie obszary Wielkiego Księstwa Litewskiego. Za archimandrii Sergiusza Kimbara grupa malarzy pod kierunkiem „Serbina Nektarego malarza” ozdobiła wnętrze świątyni freskami. Ławrę supraską odwiedzało wielu mnichów i dostojników z Bałkan w tym powracający z Moskwy patriarcha carogrodzki Jeremiasz II i patriarcha Serbski i Bułgarski Gabriel. Bliskie relacje monasteru z Kijowem, Słuckiem, Wilnem, Moskwą, Serbią, Wołoszczyzną, Bułgarią i ze św. Górą Athos pozwoliły na skoncentrowanie w nim dorobku kulturowego wielu narodów słowiańskich. Oddziaływanie kultur narodów wschodniosłowiańskich i bałkańskich uwidoczniło się na terenie monasteru w architekturze i malarstwie ikonograficznym, wystroju i wyposażeniu świątyń oraz w zbiorach biblioteki klasztornej.
\end{abstract}

Keywords: Monastery of Suprasl, Cultural relations, Serbian culture

Słowa kluczowe: monaster supraski, relacje kulturowe, kultura serbska

Monaster supraski był w XVI wieku jednym z największych prawosławnych ośrodków zakonnych na ziemiach Wielkiego Księstwa Litewskiego. Na temat jego powstania i dziejów ukazały się liczne opracowania w historiografii polskiej i obcej1. Na podstawie obszernej lite-

\footnotetext{
Za podstawowe należy uznać prace: S. Alexandrowicz, Nowe źródto ikonograficzne do oblężenia Połocka w 1579 r., „Kwartalnik Historii Kultury Materialnej”, R. XIX, Warszawa 1971, z. 1; А. Белецкий, Muтрополить Іосифь II Солтанъ и отношение его къ Супрасльскому монастырю, Вильна 1899; В. А. Чантурия, История архитектуры Белоруссии, Минск 1969; М. Cubrzyńska-Leonarczyk, Oficyna supraska 1695-1803, Warszawa 1993; Николай (Далматов), Супрасльский Благовещенский монастырь, Санкт-Петербург 1892; Модест (Стрельбицкий), Супрасльский Благовещенский монастырь, „Вест-
}

ник Западной России. Историко-литературный журнал”, г. V, кн. 2, т. І, отд. 2, Вильно 1867; Ф. Н. Добрянский, Описание рукописей Виленской публичной библиотеки, иерковнославянских и русских, Вильна 1882, с. XXVII-XXXIII; M. Hajduk, Sanktuarium nad Supraśla, „Slavia Orientalis", t. XXXVIII, nr 3-4, 1989; И. И. Иодковский, Церкви приспособленные к обороне в Литве и Литовской Руси, „Древности”, т. VI, Москва 1915; М. С. Кацэр, Белорусская архитектура, Минск 1969; W. Kochanowski, Pobazyliański zespót architektoniczny w Supraślu, „Rocznik Białostocki”, nr 4, Białystok 1963; Z. Lebiedzińska, Freski z Supraśla. Katalog wystawowy, Kraków 1968; J. Maroszek, Kalendarium klasztoru Ojców Bazylianów w Supraślu - czasy Aleksandra Chodkiewicza, „Białostocczyzna”, nr 2(34), 1994; A. Mironowicz, Supraśl jako ośrodek kulturalno-religijny w XVI wieku, Leiman 1984; tenże, Kodeks supraski, „Białostocczyzna”, nr 1(9), 1988; tenże, Zwiąki literackie Kijowa z monasterem supraskim w XVI wieku, „Slavia Orientalis”, t. 
ratury wiemy o jego założycielach i pierwszych przełożonych ośrodka zakonnego. Według najnowszych ustaleń początki klasztoru sięgały roku 1495 (1492?), kiedy wojewoda nowogródzki i marszałek hospodarski Aleksander Chodkiewicz (ok. 1457-1549) ufundował zgromadzenie zakonne w pobliżu Gródka. Data ta jest wielce prawdopodobna, zważywszy, że wcześniej z niewoli tatarskiej została uwolniona żona Iwana Chodkiewicza - Agnieszka z synem Aleksandrem i córką Agrafią. Wracając od Złotej Ordy Chodkiewiczowie zaprosili do swych dóbr uciekających przed Turkami mnichów. Według tradycji ustnej owi mnisi mieli pochodzić ze św. Góry Athos i z Ławry Kijowsko-Pieczerskiej ${ }^{2}$. Pogląd ten uwiarygodnia ogromne doświadczenie duchowe mnichów już na początku XVI wie$\mathrm{ku}$, posiadanie przez nich licznej literatury religijnej i ksiąg liturgicznych pochodzących z Bałkanów oraz późniejsze ścisłe kontakty monasteru supraskiego ze św. Górą Athos ${ }^{3}$. Szczególną rolę przy powstaniu wspólnoty monastycznej nad rzeką Supraśl odegrał Pafnucy Sieheń i Aleksander Chodkiewicz'. Na prośbę ihumena Pafnucego Siehenia

XXXVIII, nr 3-4, 1989; tenże, Podlaskie ośrodki i organizacje prawosławne w XVI i XVII wieku, Białystok 1991; tenże, Tożsamość i tolerancja $w$ rozumieniu prawosławnych zakonników supraskich $w$ XVI wieku, „Rocznik Teologiczny”, R. XL, z. 1-2, Warszawa 1998; tenże, Życie monastyczne na Podlasiu, Białystok 1998; tenże, Największa fundacja Aleksandra Chodkiewicza. Spór o charakter fundacji, [w:] Władza i prestiz. Magnateria Rzeczypospolitej w XVI-XVIII wieku, pod red. J. Urwanowicza, Białystok 2003; tenże, Summariusz dokumentów do dóbr supraskich, Białystok 2009; tenże, Sumariusz dokumentów dóbr supraskich, vol. II, Białystok 2011; tenże, Powstanie monasteru supraskiego, „Białostockie Teki Historyczne", nr 10, Białystok 2012; tenże, O początkach monasteru supraskiego i jego fundatorach, Supraśl 2013; M. Morelowski, Zarys syntetyczny sztuki wileńskiej od gotyku do neoklasycyzmu z przewodnikiem po zabytkach między Niemnem a Dźwina, Wilno 1939; М. А. Оболенский, Супрасльская рукопись, содержашая Новгородскую и Киевскую сокращенные летописи, Москва 1836; С. Петковић, Нектарие Србин, сликар $X V$ в., „Зборник за ликовне уметности”, нр. VIII, Нови Сад 1972; Н. И. Петров, Супрасльский монастырь как защзитник православия в XVI и в начале XVII века, „Виленский календарь на 1896 год”, Вильно 1895; П. П. Покрышкин, Благовещченская ичерковь в Супрасльском монастыре, [в:] Сборник археографических статей поднесеный графу А. А. Бобринскому, Санкт-Петербург 1911; А. И. Рогов, Литературные связи Белоруссии с балканскими странами в XV-XVI вв., [в:] Славянские литературы. VIII Международный съезд славистов, Загреб-Любляна, сентябрь 1978 г. Доклады советской делегаџии, Москва 1978; tenże, Фрески Супрасля, [в:] Древнерусское искусство. Монументальная живопись XI-XVII вв., Москва 1980; St. Stawicki, Czy Nektarij autor ,,Typika” byt autorem malowidel supraskich?, „Biuletyn Historii Sztuki”, Warszawa 1972, R. XXXIV, nr 1; Супрасълски или Ретков сборник, Й. Заимов, увод и коментар на старобългарски текст, М. Капалдо, подбор и коментар на гръцкия текст, т. I, София 1982, т. II, София 1983; Супрасльская летопись, [в:] Полное собрание русских летописей (dalej: ПСРЛ), т. XXXV, Москва 1980; S. Szymański, Freski z Supraśla. Próba rekonstruowania genealogii, „Rocznik Białostocki”, t. XI, 1972; A. Szyszko-Bogusz, Warowne zabytki architektury kościelnej w Polsce i na Litwie, [w:] Sprawozdanie Komisji do badań nad historia sztuki w Polsce, T. IX, z. 3-4, Kraków 1914; 500 lat monasteru w Supraślu, Supraśl 1998.

Модест (Стрельбицкий), Супрасльский Благовещенский монаcmырь, „Вестник Западной России”, г. V, кн. 7, т. 2, отд. 2, 1867, c. $71-72$.

3 A. Mironowicz, Zwiąki monasteru supraskiego ze Święta Góra Athos w XVI wieku, [w:] Święta Góra Athos w kulturze Europy. Europa w kulturze Athos, pod red. M. Kuczyńskiej, Gniezno 2009, s. 122-134.

4 J. Jasnowski, Chodkiewicz Aleksander, „Polski Słownik Biograficzny”, t. III, Kraków 1937, s. 354; Por. wypisy Józefa Wolffa dotyczące Chod-
Aleksander Chodkiewicz około 1497 roku w Gródku wybudował bądź wyremontował zamek obronny, który miał chronić monaster.

Od pierwszych lat funkcjonowania monaster supraski utrzymywał ścisłe kontakty z podobnymi centrami w kraju i za granicą, i wkrótce stał się jednym z największych prawosławnych ośrodków zakonnych na terenie Wielkiego Księstwa Litewskiego w XVI wieku. Bliskie relacje monasteru z Kijowem, Słuckiem, Wilnem, Moskwą, Serbią, Wołoszczyzną, Bułgarią i ze św. Górą Athos pozwoliły na skoncentrowanie w nim dorobku kulturowego wielu narodów słowiańskich. Ten najbardziej wysunięty na zachód prawosławny ośrodek klasztorny przekształcił się w drugiej połowie XVI wieku w centrum religijne i kulturowe o znaczeniu ogólnosłowiańskim.

Powstanie monasteru związane było z osobą Pafnucego Siehenia, pierwszego ihumena supraskiego i autora Субботника или Поминника ${ }^{5}$. Z treści wpisu do supraskiego Субботника или Поминника wynika, że założycielem monasteru był Pafnucy Sieheń pochodzący rodem z Bielska. Ihumen Pafnucy świadomie dokonał zapisu w Субботнику или Поминнику swego mieszczańskiego rodu wśród metropolitów, biskupów, panujących, kniaziów prawosławnych i innych dygnitarzy z Wielkiego Księstwa Litewskiego. „Здъ родъ Пахнотіевъ и пана Ивана Сегеневичъ изъ братіею его". Sieheniewiczowie zostali potraktowani na równi z dostojnikami duchownymi i świeckimi. Powstaje pytanie: czy takie wyeksponowanie rodziny wynikało li tylko z tego, że pierwszym ihumenem supraskim był pochodzący z tego rodu Pafnucy, czy też wynikało z faktu, że został on w latach następnych ordynariuszem dwóch najbogatszych diecezji prawosławnych: włodzimiersko-brzeskiej (1512-1522) i łucko-ostrogskiej (1523-1528) ${ }^{7}$. Szczególny szacunek i uznanie rodzina Sieheniów miała też $\mathrm{z}$ innych powodów.

Pafnucy Sieheń został nie tylko założycielem monasteru, ale jego pierwszym przełożonym. To głównie on przyczynił się do powstania pierwszych świątyń, zabezpieczenia materialnego klasztoru i określenia jego statusu w Cerkwi. Nie ulega wątpliwości, że to rodzina Siehe-

kiewiczów zamieszczone w artykule Zygmunta Luby-Radzimińskiego, gdzie stwierdzono: „Około tego czasu (1495) pan Aleksander (...) zapisuje fundusz na monaster supraślski”. Z. Luba-Radzimiński, Sprawa odrębnego pochodzenia Chodkiewiczów litewskich i białoruskich, „Rocznik Polskiego Towarzystwa Heraldycznego", t. VIII, R. 1926-1927, Kraków 1928, s. 109-132. O rodzie Chodkiewiczów i jego przedstawicielach, por.: K. Niesiecki, Herbarz polski, t. III, Lipsk 1839, s. 48-63; J. Kamiński, Rodzina Chodkiewiczów herbu Gryf, „Skarbiec Polski”, 1859; S. K. Kossakowski, Monografie historyczno-genealogiczne niektórych rodzin polskich, t. I, Warszawa 1876, s. 40-64; T. Żychliński, Złota księga szlachty polskiej, R. XI, Poznań 1889, s. 1-34; A. Boniecki, Herbarz polski, t. III, Warszawa 1900, s. 21-29; S. Uruski, Rodzina, t. II, Warszawa 1905, s. 207-215.

A. Mironowicz, Najstarszy Субботник или Поминник mоnasteru supraskiego, „Białoruskie Zeszyty Historyczne”, nr 40, Białystok 2013, s. 233-243; tenże, Subotnik ili Pominnik monasteru supraskiego, Białystok 2015 .

6 Biblioteka Litewskiej Akademii Nauk, f. 19, nr 89, s. 180; Николай (Далматов), Супрасльский Благовещенский монастырь, с. 7.

Szerzej, por.: A. Mironowicz, Nieznane losy pierwszych ihumenów supraskich, Białystok 2015. 
niów poniosła koszty założenia wspólnoty monastycznej w Gródku. Trudno uwierzyć, że takimi środkami dysponowali niedawno co uwolnieni z niewoli tureckiej Chodkiewiczowie. Nie znamy też innych współfundatorów owego przedsięwzięcia. Wybranie na przełożonego monasteru Pafnucego Siehenia, rodem z okolicznego Bielska, a niedoświadczonego mnicha ze św. Góry Athos czy Kijowa nasuwa przypuszczenie, że we współfinansowaniu pierwszych budynków klasztornych uczestniczyli przedstawiciele rodu Sieheniewiczów. Субботник или Поминник podaje jednoznacznie, że monaster powstał „верую и любовію желаніем и трудом многогрешнаго священно-инока Пафнотія, родом из Бельска". А więc nieprzypadkowo w tym źródle przedstawiciele tego rodu zostali wpisani po prawosławnych metropolitach, biskupach i najwybitniejszych dygnitarzach świeckich. Prawdopodobnie w fundacji monasteru uczestniczył burmistrz Bielska Iwan Sieheniewicz, prowadzący rozległe interesy z Chodkiewiczami, Radziwiłłami, Sapiehami i innymi urzędnikami hospodarskimi ${ }^{8}$.

Sieheniewiczowie, którzy współfinansowali budowę monasteru, uzyskali tereny do wyrębu lasu i prawo handlowania drzewem w Puszczy Błudowskiej'. Iwan Sieheniewicz i jego brat Wasyl 10 lutego 1514 roku otrzymali od króla Zygmunta Starego potwierdzenie na ziemię w Studziwodach (Iwan) oraz Puchałowszczyznę i Hryniewicze (Wasyl). Z dokumentu tego możemy wywnioskować, że król Aleksander nadał Studziwody przodkowi Iwana Siehenia - Protasowi Tyszkiewiczowi, które następnie przeszły na rzecz jego i jego żony. Z kolei brat Iwana Siehenia - Wasyl nabył od ziemianina bielskiego Mikołaja Petrykowskiego dwie wsie: Puchałowszczyznę i Hryniewicze (Hryniewszczyzna). Ponadto Iwan Sieheń otrzymał zgode na założenie w dobrach Studziwody młyna na rzece Białej, który został nazwany „Rimarewski”. Zygmunt Stary dodatkowo nadał Iwanowi Sieheniowi kawałek pola po rzekę w kierunku Szydłowa i drogę brzeską ${ }^{10}$. Z powyższego wynika, że rodzina Sieheniów była już na początku XVI wieku dobrze sytuowana materialnie.

Субботник или Поминник monasteru supraskiego, w którym pierwszy ihumen Pafnucy zaczął wpisywać imiona zmarłych braci, powstał w pierwszych latach po założeniu monasteru. Do poznania okoliczności powstania monasteru i roli w tym procesie pierwszego ihumena monasteru Pafnucego Siehenia mamy dwa źródła: Kronikę Ławry Supraskiej, która została napisana przed 1748 rokiem, czyli dwa i pół stulecia po powstaniu monasteru ${ }^{11}$ i wspomniany

\footnotetext{
J. Maroszek, Pogranicze Litwy i Korony w planach króla Zygmunta Augusta: z historii dziejów realizacji myśli monarszej między Niemnem a Narwia, Białystok 2000, s. 144; A. Boniecki, Poczet rodów w Wielkim Księstwie Litewskim w XV i XVI wieku, s. 309.

9 J. Maroszek, Monografia miasta i gminy Supraśl, Supraśl 2013, s. 55.

10 „Lietuvos Metrika” (1511-1518), Knyga nr. 9, Vilnius 2002, nr 280, s. 202-203.

11 Археографический сборник документов, относящихся к истории Северо-Западной Руси, издаваемый при управлении Виленского учебного округа (dalej: АСД), т. IX, Вильно 1870, c. IV. Jego autorem był unicki hieromnich Mikołaj Radkiewicz, który znał wydarzenia sprzed 250 laty jedynie z innych dostępnych mu przekazów pisemnych. Mnich
}

wyżej Субботник или Поминник. O ihumenie Pafnucym, założycielu monasteru supraskiego i pierwszym jego przełożonym, informował wpis do oryginalnego Субботника или Поминника ${ }^{12}$. Informacje z Субботника или Поминника о ihumenie Pafnucym jako założycielu klasztoru mógł zawierać odnotowany w „Описи” napis na tablicy umieszczonej na ikonostasie - „летописецъ церковный, што на тябле”"13. Niestety, są to jedynie domysły niepotwierdzone w innych źródłach.

Informację o ihumenie Pafnucym, jako założycielu klasztoru, znajdujemy informację w narracji o powstaniu monasteru w Kronice Lawry Supraskiej: „Najprzód roku 1498 w Gródku tę ławrę albo monaster fundować zaczął Pan Miłościwy Aleksander Chodkiewicz, wojewoda nowogródzki i marszałek wielki W. X. Lit. w dobrach swoich dziedzicznych, stąd o mil cztery, i tam na pierwszym tym funduszu osadził był zakonników św. Bazylego Wielkiego, żadnych jeszcze nie czyniąc im zapisów, i pierwszy był superior albo hegumen Paphnutiusz Sieheń. A gdy się te miejsce $\mathrm{w}$ lat dwie nie podobało zakonnikom (...) prosili fundatora (Aleksandra Chodkiewicza-A. M.), aby na innym spokojniejszym miejscu ich ufundował. Ten Pan świątobliwy, pozwolił im onego samym upatrywać i obrać. A tak już mając fundatora konsens, zrobili krzyż drewniany i puścili z Gródka rzeką Supraślem, tą intencją, gdzie na którym miejscu stanie, tym się mieli kontentować (...)". Tradycja głosi, że mnisi pomodliwszy się puścili na wodę krzyż z cząstką „świętego drzewa" ${ }^{14}$. Według tego źródła, na początku wybudowano niewielką drewnianą cerkiew św. Jana Teologa i cele dla braci. W kronice podano informację, że za ihumena Pafnucego w 1503 roku rozpoczęto budowę wielkiej cerkwi. Wspomniane zapisy o budowie cerkwi wskazują, że dotyczyły one świątyń w Gródku. „У пана Александра Ивановича Ходкевича у

ten nie dbał o ustalenie prawdziwych faktów historycznych, a jedynie starał się udowodnić unickie początki monasteru. Wersja rękopiśmienna Kroniki Ławry Supraskiej znajduje się w zbiorach Biblioteki Litewskiej Akademii Nauk w Wilnie, f. 16, B 2, № 134. Źródło we fragmentach zostało opublikowane w АСД, т. IX, Вильно 1870. Por.: J. Maroszek, Rewelacyjne odkrycie nieznanych najstarszych dokumentów dla Białegostoku, „Białostocczyzna”, nr 1 (53), 1999, s. 5-30. Istniała jeszcze inna, zaginiona, kronika supraska pod łacińskim tytułem Traditio de translatione fratrum religiosum Grodeco-Supraslum, nie wiadomo kiedy i przez kogo napisana w XVIII w. Na ową kronikę powoływał się archimandryta wileński Modest (Strelbickij) w swej monografii o monasterze supraskim z 1867 roku. Модест (Стрельбицкий), Супрасльский Благовещенский монастырь, „Вестник Западной России”, г. IV, кн. 7, т. III, отд. 2, Вильно 1865/1866, Приложения, № 1, с. 72. Por.: „Вестник Западной России", г. V, кн. 7, т. II, отд. 2, 1867, с. 71.

12 АСД, т. IX, с. 454-455; Е. Н., [Епископ Никанор], Старый Синодик Супрасльского монастыря, „Гродненские Епархиальные Ведомости”, 1904, № 27, с. 789; Модест (Стрельбицкий), Супрасльский Благовещенский монастырь, „Литовские Епархиальные Ведомости”, 1865, № 3, с. 75-76; Модест (Стрельбицкий), Супрасльский Благовещенский монастырь, „Вестник Западной России. Историко-литературный журнал”, г. V, кн. 6, т. II, отд. 2, Вильно 1867, с. 128-131; А. Белецкий, Митрополитъ Іосифъ II Солтанъ и отношение его къ Супрасльскому монастырю, с. 5-6.

13 „Опись вещам Супрасльскаго монастыря”, АСД, т. IX, c. 52. Por.: Н. Н. Улащик, Введение в изучение белорусско-литовского летописания, Москва 1985, с. 35.

$14 A C$, т. IX, c. $1-2$. 
отчизной пущи Блудовской, на край рекы Супрасли"15. $\mathrm{Z}$ okazji wyświęcenia nowej cerkwi biskup smoleński Józef Sołtan (1504-1507) ofiarował monasterowi bogato ozdobioną ewangelię, a metropolita Iona III (1502-1507) krzyż z cząstką Krzyża Świętego ${ }^{16}$. Z napisu na bocznych ściankach krzyża wynika, że dar metropolity Iony nastąpił w obecności biskupa smoleńskiego Józefa, władyki włodzimiersko-brzeskiego Wassiana II (1500-1512), ordynariusza diecezji chełmskiej Aleksandra (1503-1504) ${ }^{17}$ oraz wielu innych osób duchownych i świeckich ${ }^{18}$.

Fakt obecności na uroczystości tylu dygnitarzy duchownych i świeckich wskazuje na rangę tego ośrodka. Czy takie spotkanie byłoby możliwe na terenie do tego nieprzygotowanym, w samej puszczy? Przyjazd metropolity Iony z trzema biskupami (Józefem, Wassianem, Aleksandrem) był wielkim wydarzeniem i miał miejsce w zamku Aleksandra Chodkiewicza. Nie mniej kosztowny był inny podarunek władyki smoleńskiego. Biskup przekazał monasterowi kopię ikony Matki Bożej Smoleńskiej, która wkrótce stała się obiektem wielkiego kultu ${ }^{19}$. Ofiarowanie przez metropolitę kijowskiego Ionę monasterowi krzyża z cząstką Krzyża Świętego mogło nastąpić w dniu poświęcenia wielkiej cerkwi w 1503 roku, o czym wspomina się w Субботнику или Поминнику ${ }^{20}$. Fakt ten podważa

15 АСД, т. IX, c. 17. Pośrednio taki przebieg wydarzeń potwierdza list Zygmunta I z 12 listopada 1508 r. do wojewody trockiego Mikołaja Mikołajewicza Radziwiłła (1505-1510) nakazujący wziąć mu w opiekę dobra i poddanych monasteru nad rzeką Supraśl. Por.: Archiwum Państwowe na Wawelu, Archiwum Młynowskie Chodkiewiczów (dalej AP w Krakowie, AMCh), sygn. 36, nr 29. Strony dodatkowe nr 1.

16 Metropolita Iona otrzymał zdobiony krzyż z cząstką Krzyża Świętego od królowej Heleny, która z kolei dostała go w 1503 r. od swej matki Zofii Paleolog. Żona cara Iwana III przekazała tę bezcenną relikwię córce będąc na łożu śmierci. Е. Церетели, Елена Иоанновна, великая княгиня литовская, русская, королева польская, Санкт-Петербург 1899 , c. 242; E. Papée, Aleksander Jagiellończyk, Kraków 1949, s. 71-72.

17 Chodzi tu o biskupa chełmskiego Aleksandra - Aleksego Zbaraskiego. Kniaź Aleksander Zbaraski zmarł w 1504 roku. А. Петрушевич, Холмская епархия и святители ее, Львов 1867, с. 32. В. І. Ульяновський, Історія ичеркви та релігійної думки в Україні у трьох книгах. Кн.1: Середина XV-кінеи XVI століття, Київ 1994, s.103; J. Wolff, Kniaziowie litewsko-ruscy od końca czternastego wieku, Warszawa 1895, s. 618. 18 Na krzyżu wymienieni zostali, tylko z imienia: książę Wasyl, ,rabowie Boży": Stefan, Sidor, Semeon, Grzegorz, Michał, Iwan, Iona, Iwan, Tymoteusz, Filimon, Andrzej, Akint, Sisos - ikonograf, Włas i ihumen Pafnucy. Николай (Далматов), Супрасльский Благовещенский монастырь, с. 456. Imiona osób świeckich i duchownych wskazują, że były to następujące osoby: ihumen supraski - Pafnucy, protopop wileński - Tymoteusz, archimandryta ławryszewski - Iona. Imiona nie pozwalają dokładnie ustalić kim były wszystkie pozostałe osoby biorące udział w akcie obdarowywania. Prawdopodobnie książę Wasyl to książę Wasyl Lwowicz Gliński, podstoli litewski (1501-1507); Stefan - to Stefan Czapla, bojarzyn Aleksandra Chodkiewicza; Grzegorz - to Hrehory Isajewicz Hromyka, diak, pisarz wielki litewski (1499-1533); Semen Jurjewicz Holszański marszałek ziemi wołyńskiej (1501-1505); pierwszy z Iwanów to Iwan Iwanowicz Zabrzeziński - marszałek hospodarski (1503-1516), a drugi - Iwan Semenowicz Sapieha, kanclerz królowej Heleny (1501-1506); Sisosa - ikonograf, to Sisoj (Sysoja) diak, pisarz wielki litewski (1495-1503).

19 А. Белецкий, Митрополить Іосифь II Солтанъ и отношение его къ Супрасльскому монастырю, с. 19; Николай (Далматов), Супрасльский Благовещенский монастырь, с. 455-456, 464.

$20 \mathrm{Na}$ pierwszych kartach oryginalnego tekstu znajdowały się zapisy o charakterze kronikarskim, które informowały o powstaniu klasztoru. АСД, т. IX, s. 454-459; Е. Н., Старый Синодик Супрасльского мо- wiarygodność legendy o spuszczeniu krzyża rzeką Supraśl w 1500 roku. W tym bowiem roku mnisi koło Gródka nie posiadali takowej relikwii.

Gdyby literalnie trzymać się zapisu z kopii Субботника или Поминника z 1631 roku, to powstanie monasteru w Gródku należałoby odnieść do roku 1492 roku. „По благодати СвАтого Духа и Божественньй и Животданнъй Тройци славимому Богоу въ льто от начала мира 7000 - го, индикта 3 - го, дозволениемъ вельможного пана Александра Ивановича Ходковича начасл съзидати сій монастыр оу его отчинной пущи Блоудовской, на край рьки Супрлслы, върую и любовию, желаніемъ и трудом многогрђшнаго свАщенно-инока игумена Пафнотїа, родом из БЪльска"21. Z powyższego zapisu możemy wnioskować, że monaster powstał już w 1492 roku. Powstaje pytanie: czy była to tylko pomyłka kopisty mnicha Stefana Kochaniewicza, czy mylili się inni badacze oglądając oryginalny Субботник или Поминник z początku XVI wieku? Monaster w Gródku nad rzeką Supraśl mógł rzeczywiście powstać w 1492 roku, albowiem żona Iwana Chodkiewicza - Agnieszka, córka ks. Iwana Bielskiego, wydostała się z niewoli wraz z synem Aleksandrem i córką Agrafią przy pomocy Kazimierza Jagiellończyka. Król zmarł w 1492 roku, a więc wydarzenie to miało miejsce między 1484 a 1492 rokiem $^{22}$.

настыря; „Гродненские Епархиальные Ведомости”, Годъ IV, 1904, № 27, с. 789; Ф. Н. Добрянский, Описание рукописей Виленской публичной библиотеки, церковнославянских и русских, № 89, с. 180; Николай (Далматов), Супрасльский Благовещенский монастьрь, с. 7; А. Белецкий, Митрополить Іосифь ІІ Солтанъ и отношение его къ Супрасльскому монастьрю, с. 5-6.

Biblioteka Litewskiej Akademii Nauk, f. 19, nr 89. Oryginalny rękopis skopiował mnich supraski Stefan Kochaniewicz, który wprowadził do pierwotnego tekstu liczne dodatkowe wpisy. Tamże, k. 8.; A. Naumow, Monaster supraski jako jeden z głównych ośrodków kulturalnych Rzeczypospolitej, [w:] Z dziejów monasteru supraskiego, Supraśl - Białystok 2005, s. 110.

21 „Въ льто отъ начала міру 7000, индикта 3, дозволеніем вельможнаго пана Александра Ивановича Ходкевича начсать съзидатися сей монастырь у его отчинной пущи Блудовской, на край рьки Супраслы. ВЪрую и любовію, желаніем и трудом многогрђшнаго священно-инока Пафнотія, родомъ изъ БЪльска. И первђе съоружися церковъ невелика во имя свястаго Іоанна Богослова и святися нареченнымъ митрополитомъ Іосифомъ и трапеза на прихожденіе братіи. Потом в лето 7011, индикта 7, съоружена бысть великая церква Пречистыя Богоматери, Честнаго Ея Благовъщенія, со придълы святых великомучениковъ Бориса и Глъба, нареченных во св. крещеніи Романа и Давида и преподобных св. Отец строителей Печерскихъ и начальникъ общему житію, Антонія и Феодосія, Богоспасаемаго града Кіева в Рустьй земль. Сія же Божія церкви освящены были освященнымъ епископомъ, нареченнымъ митрополитомъ Кіевскимъ и всея Руси күръ Іоною, мъсяца октябра в 15 день, на память преподобнаго отца нашего Евфимія новаго и св. Мученика Лукіана, пресвитера великія Антіохіи, индикта 7". Коріа zapisu z oryginalnego sinodnika została wykonana w 1631 r., por.: Biblioteka Litewskiej Akademii Nauk w Wilnie, f. 19, nr 89, k. 8; Прадмова да Памянніка ці Сінодыка з Супрасльскага манастыра 1631 г. (опр. Л. В. Ляўшун), [в:] Рэлігійнае Пісьменства Кірылічнай Tрадыцыі XI-XV cmст., Мінск 2013, с. 547; Модест (Стрельбицкий), Супрасльский Благовещзенский монастырь, „Литовские Епархиальные Ведомости”, 1865, № 3, с. 75-76; Николай (Далматов), Супрасльский Благовещенский монастырь, с. 7; А. Белецкий, Митрополить Іосифь II Солтанъ и отношение его къ Супрасльскому монастырю, с. 5-6.

22 J. Jasnowski, Chodkiewicz Iwan, s. 361. Szersze rozważania na ten temat, por.: A. Mironowicz, O początkach monasteru supraskiego i jego 
Funkcjonowanie monasteru w pobliżu dworu w Gródku nad rzeką Supraśl okazało się niewygodne. Życie dworskie utrudniało praktyki religijne, a zwłaszcza prowadzenie życia pustelniczego przez mnichów. $\mathrm{Z}$ tego powodu ihumen z mnichami zwrócił się do Aleksandra Chodkiewicza z prośbą o pozwolenie na przeniesienie klasztoru na inne miejsce ${ }^{23}$. Mnisi poprosili o przeniesienie klasztoru w dół rzeki Supraśl. Na prośbę ihumena Pafnucego Siehenia Aleksander Chodkiewicz, „намовившися” z osobami duchownymi, wyraził zgodę na nową lokalizację. Owe zdarzenie miało miejsce nie wcześniej aniżeli w 1507 roku, kiedy drugi fundator monasteru biskup smoleński Józef Sołtan został metropolitą kijowskim. Jego chirotonia na metropolitę nastąpiła dopiero w maju 1507 roku. Zmiana lokalizacji monasteru spowodowała, że część mnichów powróciła do Kijowa, a pozostała przeniosła się na uroczysko Suchy Hrud, dając początek Ławrze Supraskiej$^{24}$. Jeżeli pomysł przeniesienia monasteru pojawił się w 1507 roku, to klasztor nie mógł od razu rozpocząć swojego funkcjonowania na nowym miejscu. Potrzebna była budowa nowych świątyń na uroczysku Suchy Hrud. Prawdopodobnie mnisi pozostawali w Gródku w pobliżu zamku Chodkiewiczów do końca 1507 roku.

W źródłach informujących o monasterze supraskim do czasu jego przeniesienia na nowe miejsce nie ma danych odnośnie jego lokalizacji, albowiem wyznacznikiem był zamek Chodkiewiczów. Dopiero późniejsze akta precyzyjnie lokują nową siedzibę klasztoru na brzegu rzeki Supraśl, na uroczysku Suchy Hrud, między rzekami Berezówką i Grabówką. Początkowo w Gródku mnisi żyli według reguł hagioryckich monasterów skitskich. Zakonnicy mieszkali w swych leśnych celach, a tylko w sobotę i niedzielę zbierali się w cerkwi na wspólnych nabożeństwach. Źródła nie wymieniają wezwania świątyni, ale prawdopodobnie była to cerkiew św. Jana Teologa, o której mówi się w Субботнику или Поминнику ${ }^{25}$.

Wojna litewsko-moskiewska, prowadzona na początku XVI wieku, przebiegała głównie na wschodnich rubieżach

fundatorach, Supraśl 2013; tenże, Największa fundacja Aleksandra Chodkiewicza. Spór o charakter fundacji, [w:] Władza i prestiż. Magnateria Rzeczypospolitej w XVI-XVIII wieku, pod red. J. Urwanowicza, Białystok 2003, s. 529-550.

${ }^{23}$ Archimandryta Modest przyjął datę przeprowadzki po 1500 r. Datę tę trudno jest zaakceptować, albowiem wówczas Józef Sołtan nie był nawet biskupem. Również podana przez niego informacja o wyświęceniu nowej cerkwi św. Jana Teologa na Suchym Hrudzie 25 maja 1505 r. nie znajduje żadnego logicznego wytłumaczenia. Biorąc pod uwagę okres, kiedy biskup Józef został „nareczenny” na metropolitę (luty 1507 r.) pośrednio datę roczną decyzji o przeniesieniu na nowe miejsce można wyznaczyć na drugą połowę 1507 r. Модест (Стрельбицкий), Супрасльский Благовещенский монастырь, „Вестник Западной России”, г. V, кн. 7, т. 2, отд. 2, 1867, с. 71-73. Chirotonia biskupa Józefa Sołtana na metropolitę odbyła się 10 maja 1507 r. „Вестник Западной России”, г. IV, кн. 7, т. III, отд. 2, Вильно 1865/1866, с. 2. Według innych źródeł władyka Józef był ,nareczenny” jeszcze 26 lutego 1508 r. „Lietuvos Metrika” (14991514), Knyga nr. 8, Vilnius 1995, nr 110, s. 143.

${ }^{24}$ АСД, т. IX, с. 2, 42. A. Mironowicz, O poczatkach monasteru supraskiego i jego fundatorach, s. 12-18; Rękopisy supraskie w zbiorach krajowych i obcych, opr. Antoni Mironowicz, Białystok 2014, s. 11-50.

25 Николай (Далматов), Супрасльский Благовещенский монастырь, c. 6; А. Белецкий, Митрополитъ Іосифъ ІІ Солтанъ и отномение его къ Супрасльскому монастырю, с. 12.
Wielkiego Księstwa Litewskiego, zwłaszcza na Smoleńszczyźnie. Słudzy Chodkiewicza informowali tamtejszego biskupa smoleńskiego Józefa Sołtana o monasterze prawosławnym powstałym nad rzeką Supraśl. Władyka smoleński doskonale zdawał sobie sprawę z rangi powstałego monasteru i kiedy w 1504 roku otrzymał od króla Aleksandra za zasługi w wojnie z Moskwą oraz utracone majątki sześć służb kmiecych we włości suraskiej, przekazał je monasterowi ${ }^{26}$. Formalne nadanie nastąpiło 11 maja 1506 roku, kiedy władyka Józef nawiązał bezpośrednie kontakty z Aleksandrem Chodkiewiczem ${ }^{27}$. Na podstawie źródeł trudno jest ustalić jaką rolę w tych nadaniach odegrał ihumen Pafnucy Sieheń.

$\mathrm{Na}$ pewno przełożony monasteru współpracował z władyką smoleńskim. Prawdopodobnie przy jego pomocy, a może na jego prośbę biskup Sołtan wraz z ktitorem opracowali nowy regulamin życia w monasterze. Reguła ta zasługuje na szczególną uwagę, albowiem określała ona zasady wyboru przełożonego monasteru. Nie ktitorzy - jak było powszechnie przyjęte na terenie Wielkiego Księstwa Litewskiego - decydowali o wyborze ihumena, a sami zakonnicy. Mnisi wybierali swego przełożonego spośród siebie. Taki sposób wyboru ihumena świadczył o sile i doświadczeniu duchowym zakonników będących w monasterze. Liczba zakonników musiała być duża, a większość $\mathrm{z}$ nich musiała mieć długą praktykę życia zakonnego ${ }^{28}$.

Pafnucy Sieheń doprowadził do stworzenia dobrze zorganizowanej wspólnoty zakonnej. Surowe zasady życia w utworzonym monasterze, w zamiarze fundatorów, miały doprowadzić do powstania ośrodka zakonnego, w którym przebywaliby mnisi o wysokiej moralności, prowadzący ascetyczny obraz życia. Swoją postawą mnisi mieli przyciągnąć do siebie nie tylko prawosławnych, ale i innowierców. Zasady życia w klasztorze, opracowane przez Aleksandra Chodkiewicza i Józefa Sołtana, zostały wysłane do patriarchy Joachima $\mathrm{I}^{29}$ w celu ich zatwierdzenia. Sam król Aleksander poinformował patriarchę konstantynopolitańskiego o fakcie założenia przez Aleksandra Chodkiewicza monasteru w swych dobrach - lasach Błudowskich, na

26 „Вестник Западной России”, г. IV, кн. 7, т. III, отд. 2, Вильно 1865/1866, c. 1-6; Hieronim Grala datuje owe wydarzenie na wrzesień 1503 roku, H. Grala, Kotpak Witołdowy czy czapka Monomacha? (Dylematy wyznawców prawosławia w monarchii ostatnich Jagiellonów), [w:] Katolicyzm w Rosji i prawosławie w Polsce (XI-XX w.), Warszawa 1997, przyp. 3, s. 61 .

27 Kopia dokumentu por.: AP w Krakowie, AMCh, sygn. 36, nr 29, k. 81-83; АСД, т. IX, с. 6-7; „Вестник Западной России”, г. V, кн. 7, т. I, отд. 2, Вильно 1867, с. 6-9; List króla Aleksandra nadający biskupowi smoleńskiemu Józefowi Sołtanowi dobra Baciuty, Topilec i Piszczewo z 15 września 1504 r., por.: АСД, т. IX, c. 8-9 (wydrukowany z mylną datą roczną).

28 Według metropolity Makarego w monasterze supraskim przybywało 40 mnichów, nie licząc nowicjuszy i innych. Por.: Митрополит Макарий (Булгаков), История Русской Церкви, кн. V, Москва 1996, с. 168.

29 Mowa tu o patriarsze konstantynopolitańskim Joachimie I (1498-1502; 1504). Tomos patriarszy został wystawiony prawdopodobnie w 1504 r., a do monasteru dotarł rok później. Kopia tomosu przechowywana w monasterze posiadała zapewne datę roczną 1505 r. Por.: АСД, т. IX, c. 3-5; „Вестник Западной России”, г. V, кн. 1, т. I, отд. 2, Вильно 1867, Приложения, с. 1-3; Summariusz dokumentów do dóbr supraskich, s. $54-55,136$. 
brzegu rzeki Supraśl. Również właściciel Gródka napisał do patriarchy list, w którym informował adresata o wybudowaniu przez siebie ,znamienitej cerkwi” ku czci Bogurodzicy i przekazaniu środków na funkcjonowanie monasteru $^{30}$.

Patriarcha Joachim I z radością przyjął wspomniane pisma, podziękował ktitorom monasteru Aleksandrowi Chodkiewiczowi i biskupowi Józefowi Sołtanowi za ich wysiłki, a następnie przesłał błogosławieństwo klasztorowi i poświęcił go łaską Świętego Ducha. Patriarcha zatwierdził również regułę i zasady życia $\mathrm{w}$ monasterze ${ }^{31}$. W oryginalnym tomosie patriarszym, przechowywanym w monasterze supraskim jeszcze w 1867 roku, znajdowały się jakże znamienne sformułowania różniące się od kopii spisanej w języku łacińskim. „Іоакимъ милостью Божою Архіепискпъ Константинопольский, Новаго Рима вселеньский Патиярх. Понеже славный краль и превеликій князь всей Литвы в своихъ писанихъ показаномъ и нашой сиренности, како маршалокъ его державы Благочестивый и православный и великолепный Панъ Александро, сынъ Пана Ивана Ходкевича, отъ своего имънія и отъ своего скарбу и отъ своего труда, на своей властной отчизне и дъдине у пущи блудовской у скрай рђки Супраслы, и сфудоменту созида и вънесе честный монастырь по имени Пречистыя Владичица нашея Богородица, Честнаго Ея Благовъщенія. Такъ же своимъ посланіемъ воспомяну намъ той православный Панъ Александро, Еже и сфудоменту воздвигну тую пречистыю обитель, и приложи кней, отъ своее отчизны очемъ бы мъла церково божия на въки стояти, и живушим вней чимъ бы мъли поживитися во славу Христу Богу и родителемъ его впаметь въчную. Помеже онъ есть ктиторъ и смирение наше видячи его сердечную любовъ еже имати к Богу, ижъ оть своего труда и оть своего скарбу, постави боголюбезно оть фудомента честыю обитель. За то благославлаемъ ктиторы, Пана Александра і епископа смоленского Іосифа и труды ихъ, да есть жертва ихъ совершена къ Богу, и отъ Господа Бога милости на нихъ да есть всий въкъ и вбудущий. (...)”32.

Pafnucy Sieheń zabiegał o prawne i materialne zabezpieczenie swojego monasteru. Biskup Józef Sołtan i Aleksander Chodkiewicz 26 lutego 1507 roku w Wilnie uzyskali u króla Zygmunta Starego potwierdzenie nadania monasterowi sześciu służb kmiecych, otrzymanych przez

\footnotetext{
30 „Вестник Западной России”, г. V, кн. 7, т. I, отд. 2, Вильно 1867 с. 12-14; А. Белецкий, Митрополить Іосифь ІІ Солтанъ и отношение его къ Супрасльскому монастырю, с. 16-17.

31 W dokumencie patriarszym wspomina się o wyborze ihumena przez samych zakonników, zakazie picia alkoholu, nieopuszczania monasteru bezzgody ihumena i przestrzegania postów. „Вестник Западной России”, г. V, кн. 7, т. I, отд. 2, Вильно 1867, с. 11; Patriarcha w tomosie z 1505 r. (1504) pisał, że Aleksander Chodkiewicz założył i ufundował ,za własne środki" w swych lasach Błudowskich na brzegu rzeki Supraśl monaster „по имени Пречистыя Владичица нашея Богородица, Честнаго Ея Благовьщенія” i wspomina o wybudowaniu „tej znamienitej cerkwi”, АСД, т. IX, с. 3-5; А. Белецкий, Митрополить Іосифь II Солтанъ и отношение его къ Супрасльскому монастырю, с. 17.

32 „Вестник Западной России”, г. V, кн. 1, т. I, отд. 2, Приложения, c. 3 .
}

władykę smoleńskiego w 1504 roku $^{33}$. Potwierdzenie nadania monasterowi supraskiemu przez władykę smoleńskiego otrzymanych od króla dóbr Topilec, Baciuty i Piszczewo zawierało kilka ważnych informacji. $\mathrm{W}$ dokumencie tym wymieniona została jedynie cerkiew Zwiastowania NMP położona na skraju rzeki Supraśl w ojczyźnie Aleksandra Chodkiewicza. Czy byłoby możliwe wybudowanie cerkwi na uroczysku Suchy Hrud już w 1506 roku? Sam autor Kroniki Ławry Supraskiej uważał to za niemożliwe. „Cerkiew murowana - pisze w pominniku - że stanęła za pierwszego archimandryty Siehenia przez lat trzy, co się stać nie mogło $\mathrm{w}$ tak prędkim czasie, bo przeniosszy się z Gródka na te miejsce w roku 1500, i zastawszy tylko puszczę, trzeba było najprzód cegielnię, etc. ufundować, gliny nakopać, wapna przysposobić; a i cegła czasu nie mało weźmie na taką strukturę, zaczym moim zdaniem, mogła się zacząć za pierwszego archimandryty, a za drugiego Kaliksta zakończona jest, i pewna że kosztem fundatorskim, bo jeszcze przy początkach klasztor jakby nic nie miał’34. Z pewnością Mikołaj Radkiewicz nie miałby takich wątpliwości co do czasu budowy cerkwi Zwiastowania NMP, gdyby założył, że informacje podane w Субботнику или Поминнику dotyczą wielkiej świątyni wybudowanej na terenie pierwotnej lokalizacji monasteru, prawdopodobnie wykonanej z drew$\mathrm{na}^{35}$. W dokumencie z 11 maja 1506 roku nie wymienia się lokalizacji monasteru i cerkwi Zwiastowania NMP.

Biskup Józef Sołtan w tym samym dokumencie prosił Aleksandra Chodkiewicza, marszałka hospodarskiego, namiestnika puńskiego, o opiekę nad nadanymi monasterowi dobrami i o ochronę klasztoru. „Нижли в опеку и от кривд боронити того именья и людей и земли полецаю и приказую пану Александру Ивановичу Ходкевичу, и по нем его детем и его счадком и их бояром и слугам, для того, иж тот монастырь у его отчизне стоит. Понежъ они суть ктиторы того монастыря, они мают от всих кривд боронити (...)"36.

„Nareczenny”37 w lutym 1507 roku na godność metropolity Józef Sołtan wsparł starania mnichów o nową lokalizację monasteru. W 1507 roku hierarcha poparł u Aleksandra Chodkiewicza prośbę ihumena Pafnucego i mnichów o przeniesienie monasteru z Gródka na nowe miejsce. Władyka doskonale znał sytuację klasztoru $\mathrm{z}$ autopsji i przekonał białoruskiego magnata do wyrażenia zgody na nową lokalizację monasteru. Analizując pierwsze zapisy Aleksandra Chodkiewicza, dotyczące udostępnienia lasu do budowy nowych budynków klasztornych, można dojść do wniosku, że pierwsze inwestycje na uroczysku Suchy Hrud były drewniane. Wkrótce jednak powstała

\footnotetext{
33 AP w Krakowie, AMCh, sygn. 36, nr 29, k. 83-84; АСД, т. IX, c. 22 -24. Regest tego dokumentu wskazuje, że jego wydanie nastąpiło 17 lipca 1507 r. Prawa i przywileje miasta i dóbr ziemskich Zabłudów XV-XVIII w., oprac. J. Maroszek, Białystok 1994, s. 86.

34 АСД, т. IX, c. 25.

35 Szerzej o tym por.: A. Mironowicz, O początkach monasteru supraskiego i jego fundatorach, s. 19-24.

36 AP w Krakowie, AMCh, sygn. 36, nr 29, k. 80-82, 129-134; АСД, т. IX, c. 7.

37 "Нарєчєнны” (,nareczenny”) - nazwany, mianowany, posiadający nadaną godność, stanowisko.
} 
myśl o budowie cerkwi z kamienia. Wobec panującego na terenie Wielkiego Księstwa Litewskiego oficjalnego zakazu budowy cerkwi murowanych, wymagana była zgoda królewska na wzniesienie takiej świątyni. Ihumen Pafnucy Sieheń wystąpił z taką prośbą do króla na początku 1509 roku. W połowie marca 1509 roku Zygmunt Stary wyraził zgodę na wybudowanie murowanej cerkwi. „Бил нам челом игумен Супрасльскій Пафнутій о том, чтож он працою своею... (...) будовати монастырь в пущи пана Александра Ходкевича на реце Супраслы и просил нас о том, чтоб дозволили церковь и монастырь муровати. Ино мы з ласки нашое на его чолобите дозволили ему церковь и монастырь муровати в той пущи пана Александра Ходкевича, где ся будет видеть ему угодно будовати" ${ }^{\prime 3}$

Dopiero po uzyskaniu takiej zgody ihumen Pafnucy mógł przystąpić do zaplanowanej inwestycji. Budowę świątyni rozpoczęto w październiku 1510 roku. W 1509 roku i w pierwszych dziewięciu miesiącach roku następnego gromadzono materiały. W połowie października 1510 roku metropolita Józef odwiedził monaster. Z nadania Aleksandra Chodkiewicza wynika, że metropolita przebywał „y монастыри на реке Супраслы” ${ }^{39} .15$ października 1510 roku metropolita w swym przywileju pisze, że „нашею доброю волею и накладом соружити монастырь иноком общаго равножительства у пана Александра Ивановича Ходкевича, у отчизной пущи Блудовской, на край реки Супраслы, на острове межи источников водных - речок Грабовки и Березовки"

Już wkrótce po podjęciu decyzji o przeniesieniu klasztoru Aleksander Chodkiewicz po raz drugi potwierdził przekazanie w 1501 roku monasterowi Choroszczy: „, всем правом и панством, ни чого не оставляючи на себе и наши наследники". Potwierdzenie nadania Choroszczy było potrzebne $\mathrm{z}$ uwagi na nową lokalizację monasteru. Chodkiewicz potwierdził zasady wyboru ihumena, zachowując sobie jedynie prawo usunięcia go z monasteru, jeśliby prowadził życie niezgodne ze statutem klasztornym. Magnat wzywał ihumena do troski o majątek monasterski

\footnotetext{
38 AP w Krakowie, AMCh, sygn. 36, nr 29, k. 1; Aкты, издаваемыле Buленской комиссией для разбора древних актов, т. VII, Вильна 1874, с. 3. Николай (Далматов), Супрасльский Благовещенский монастырь, c. 45; А. Белецкий, Митрополить Іосифь II Солтанъ и отношение его къ Супрасльскому монастырю, с. 21; Модест (Стрельбицкий), Супрасльский Благовещенский монастырь, с. 75; Ф. Покровский, Археологическая карта Гроденской губерни, Вильна 1895, с. 72; Summariusz dokumentów do dóbr supraskich, s. 55.

39 Dokument jest wystawiony z datą 13 października 1510 r. АСД, т. IX, c. 13-16; „Вестник Западной России”, г. IV, кн. 7, т. III, отд. 1, Вильно 1866, с. 9-14. Po gruntownej analizie dokumentu i z uwagi na fakt, że Aleksander Chodkiewicz znajdował się w więzieniu, niesłusznie posądzony o udział w spisku księcia Michała Glińskiego, od lutego 1509 do 10 maja 1511 r. należy uznać, że nadania monasterowi supraskiemu miały miejsce w 1511 r., a nie jak wydano drukiem w 1510 r. Dokument pergaminowy z datą 13 października 1510 r. Por.: Biblioteka Muzeum Narodowego im. Czartoryskich w Krakowie, Zbiór dokumentów pergaminowych, nr 66 (MNK 541/1).

40 Николай (Далматов), Супрасльский Благовещенский монастырь, c. 19-23; А. Белецкий, Митрополить Іосифъ II Солтанъ и отношение его къ Супрасльскому монастырю, с. 22.
}

oraz zobowiązywał się do obrony jego ziem i dóbr ${ }^{41}$. Z powyższych zapisów wynika, że Pafnucy Sieheń miał pełne poparcie ktitorów i zabezpieczenie materialne przy realizacji budowy cerkwi Zwiastowania NMP. Wkrótce pozycja ihumena w monasterze ulegnie zasadniczej zmianie.

$\mathrm{W}$ ramach zabezpieczenia materialnego monaster od swego założenia do połowy XVI wieku otrzymał liczne nadania i zapisy. Klasztor wszedł w posiadanie wielu ziem i majątków: dworu i miasta Choroszcz, dóbr Chworostowo i Pużycze na Polesiu, Fast, Porosłów i Klewinowa na Podlasiu oraz nadanych przez metropolitę Józefa Sołtana wsi Topilec, Baciuty, Piszczewo ${ }^{42}$, ziemi nad rzeczką Biały Stok ${ }^{43}$,

41 Документы относящихся к истории Супрасльского монастьря, „Вестник Западной России”, г. V, кн. 7, т. II, отд. 2, Вильно 1861. Chоroszcz trafiła do Chodkiewiczów po 1470 r., a przed 1483 r. i do założenia zamku w Gródku stanowiła centrum dóbr Iwana i Aleksandra Chodkiewiczów. J. Wiśniewski, Początki Białegostoku i okolicznego osadnictwa, [w:] Studia i materiały do dziejów miasta Białegostoku, t. IV, Białystok 1985, s. 7-27; H. Surynowicz, Pod opieka Matki Bożej. Dzieje parafii prawosławnej w Choroszczy, Choroszcz 2008, s. 21. W Kronice Lawry Supraskiej dokument ten jest datowany na 13 października 1510 r. АСД, т. IX, с. 13-16; Акты, относящиеся к истории Южной и Западной России, собранные и изданные Археографической комиссиею, т. I, Санкт-Петербург 1863, с. 40-42 (dalej: АЮЗР); Акты, издаваемые Виленскою Археографическою Комиссиею, высочайше учрежденною для разбора древних актов в Вильне (dalej $A B A K)$, т. VI, Вильно 1872 , с. 3 . Krytyczne wydanie dokumentu por.: Prawa i przywileje miasta $i$ dóbr ziemskich Zabłudów XV-XVIII, s. 37-45. Zapis fundacyjny Choroszczy dla monasteru supraskiego nastapił 25 maja 1501 r. AP w Krakowie, AMCh, sygn. 36, nr 29, k. 65-71; Николай (Далматов), Супрасльский Благовещенский монастьрь, с. 488-490. W 1507 r. król nadał Choroszczy prawa magdeburskie i potwierdził wolę Aleksandra Chodkiewicza, ,Słownik Geograficzny Królestwa Polskiego i innych krajów słowiańskich” (dalej - „SGKP”), t. I, Warszawa 1880, s. 633; АСД, т. IX, c. 14-16, 22-25; Sumariusz dokumentów dóbr supraskich, vol. II, s. 130-131; Николай (Далматов), Супрасльский Благовещенский монастырь, с. 15-18. Konfirmacja przywileju Aleksandra Chodkiewicza z datą 13 października 1510 r. dana na rzecz monasteru supraskiego dokonana 31 stycznia 1623 r. przez króla Zygmunta III Wazę, por.: AP w Krakowie, AMCh, sygn. 36, nr 29, k. 3, (mikrofilm J-14603), s. 65-72 (s. 66). $42 A C Д$, т. IX, c. 8-9. Król potwierdził nadania metropolity Józefa Sołtana 11 maja 1506 r. „Lietuvos Metrika” (1387-1546), Knyga nr 25, Vilnus 1998, nr 220-222, s. 273-276. Potwierdzenie nadań Aleksandra Chodkiewicza na dobra Choroszcz na rzecz monasteru supraskiego i Józefa Sołtana na wsie Topilec, Baciuty i Piszczewo przez króla Zygmunta Starego nastąpiło 17 lipca 1507 r. АСД, т. IX, c. 22-24. W granicach uposażenia monasteru znajdowało się sześć wsi: Topilec, Baciuty, Zawady, Zaczerlany, Kościuki i Gajewniki. Uposażenie obejmowało tereny obfitujące w lasy i rzeczki, a poprzez rzekę Narew miało doskonałe połączenie z Choroszczą. Dobra te stanowiły główne zaplecze materialne monasteru i gwarantowały jego rozwój. Zygmunt Stary 23 października 1529 r. potwierdził nadanie przez Aleksandra Chodkiewicza dóbr Chworostowo i Pużycze na Polesiu oraz wsi Fasty, Porosły i Klewinowo na Podlasiu na rzecz monasteru supraskiego. АСД, т. IX, с. 40-41; $A B A K$, т. I, Вильно 1865 , c. $46-49$.

43 Na początku monaster supraski, oprócz pasu puszczańskiego między rzekami Grabówką i Brzozówką i dobrami choroskimi, posiadał ziemie sięgające do Białego Stoku, poprzez zakupienie od „ludzi królewskich pasa łąk". Ziemie te były obiektem konfliktów między monasterem a właścicielem dóbr białostockich Mikołajem Michnowiczem Raczkiewiczem. Drugim obszarem spornym były ziemie nabyte przez mnichów supraskich od Onisima Jakowlewicza Wyporadkowicza, na które Mikołaj Michnowicz otrzymał w 1509 r. również przywilej. Biblioteka Litewskiej Akademii Nauk w Wilnie, f. 16, B 2, № 134, k. 12v. Ugoda między Mikołajem Michnowiczem a ihumenem supraskim 14 grudnia 1514 r. Por.: Druk z inną datą dzienną - 11 grudnia. АСД, т. IX, c. 32-34; AP w Krakowie, AMCh, sygn. 35, k. 1-8; M. Łozowska, Fundacja klasztoru supraskiego w pierwszej połowie XVI wieku. Próba interpretacji dokumentów 
ziemi Uboczowszczyzna ${ }^{44}$, sianożęć w Karakułach ${ }^{45}$. Sam ihumen Pafnucy dokonywał licznych zakupów ziemi, powiększając tym samym stan posiadania klasztoru. Do monasteru należały ziemie pomiędzy rzeczkami Biały Stok i Supraśl, liczne bartnie i jazy oraz inne dobra. Ziemie te ihumen Pafnucy zakupił między innymi od Onisima Jakowlewicza Wyporadkowicza $^{46}$ i Maksyma Kosteniewicza ${ }^{47}$.

Za czasów Pafnucego Siehenia monaster nad rzeką Supraśl otrzymał specjalną patriarszą opiekę, a jego ihumen był tytułowany „игуменом Благовещенской патріяшей обители", czyli ihumenem monasteru patriarszego Zwiastowania NMP. Trudno znaleźć powód takiego uznania przez patriarchę konstantynopolitańskiego dla tylko co powstałego monasteru. Na pewno do objęcia patronatem patriarszym nie wystarczyły jedynie prośby jego ktitorów.

Udział ihumena Pafnucego w soborze lokalnym w Wilnie miał istotne znaczenie dla ihumena i monasteru. Sobór w Wilnie, odbywający się na przełomie 1509 i 1510 roku, ustanowił piętnaście zasad, które miały regulować relację między władzą duchowną a świecką. Celem ich było osłabienie wpływu świeckich na obsadzanie stanowisk cerkiewnych i podniesienie prestiżu władzy duchownej. Podczas obrad podjęto postanowienia dotyczące stosunku duchowieństwa do władzy świeckiej, określono sposób wyłaniania kandydatów na stanowiska kościelne, uregulowano życie kleru i kwestie sądownictwa duchownego ${ }^{48}$.

$\mathrm{Na}$ soborze wileńskim omawiano sprawę monasteru supraskiego, który uzyskał potwierdzenie swej pozycji na mocy specjalnego tomosu od patriarchy konstantynopolitańskiego Joachima ${ }^{49}$. Nic też dziwnego, że na soborze

uposażeniowych, [w:] Małe miasta. Historia i współczesność, t. I, Supraśl 2001, s. 52-53; Summariusz dokumentów do dóbr supraskich, s. 58.

44 Biblioteka Muzeum Narodowego im. Czartoryskich w Krakowie, Zbiór dokumentów pergaminowych, nr 860, t. I, k. 13; Summariusz dokumentów do dóbr supraskich, s. 58.

45 АСД, т. IX, c. 26.

46 Kopia dokumentu króla Aleksandra z 28 lipca 1505 r. potwierdzającego kupno przez ihumena Pafnucego ziemi i sianożęci w Bokiniach od Onisima Jakowlewicza Wyporadkowicza. АСД, т. IX, с. 27; „Вестник Западной России”, г. V, кн. 4, т. III, Приложения, с. 6-7; „Вестник Западной России", г. V, кн. 7, т. I, отд. 2, Вильно 1867, с. 15. Sam zakup przez mnichów supraskich terenów pomiędzy rzekami Biały Stok i Supraśl a drogą z Dojlid do Jurowiec od bojarów Wyporadkowiczów został dokonany prawdopodobnie w 1500 r. Por.: J. Maroszek, Rewelacyjne odkrycie nieznanych najstarszych dokumentów dla Białegostoku, „Białostocczyzna”, nr 1 (1999), s. 22-23.

47 AP w Krakowie, AMCh, sygn. 36, nr 29, k. 3; „Вестник Западной России”, г. V, кн. 4, т. III, с. 5-6; „Вестник Западной России”, г. V, кн. 7, т. I, отд. 2, Вильно 1867, с. 15; Summariusz dokumentów do dóbr supraskich, s. 55, 66; H. Surynowicz, Pod opieka Matki Bożej, s. 26-27.

48 „Русская Историческая Библиотека”, т. IV, s. 5-18; A. Mironowicz, Kościól prawosławny w państwie Piastów i Jagiellonów, Białystok 2003, s. 223, 225.

49 Mowa tu o patriarsze konstantynopolitańskim i ekumenicznym Joachimie I. Por. ACД, т. IX, c. 3-5; „Вестник Западной России. Историко-литературный журнал”, Вильно 1867, г. V, кн. VII, т. I, Приложения, s. 1-3; Summariusz dokumentów do dóbr supraskich, s. 54-55, 136. Митрополит Макарий (Булгаков), История Русской Церкви, т. IX, Санкт-Петербург 1879, с. 168; Акты исторические собранные и изданные Археографической комиссиею, т. I, Санкт-Петербург 1841 , c. 524-529. Na ten przywilej patriarszy powoływał się metropolita kijowski Józef Sołtan w 1514 r. АСД, т. IX, c. 5. Oryginał jest przechowywany w: AP w Krakowie, AMCh, sygn 36, nr 29; „Вестник Западной России", г. V, кн. 7, т. I, отд. 2, с. 15; Summariusz dokumentów do dóbr ojciec Pafnucy był wymieniany jako pierwszy po Jonaszu - przełożonym Ławry Kijowsko-Pieczerskiej ${ }^{50}$, bowiem monaster nad rzeką Supraśl podlegał jedynie patriarsze konstantynopolitańskiemu ${ }^{51}$.

Na soborze wileńskim 1509-1510 roku zapadła też decyzja o wyborze ihumena supraskiego Pafnucego Siehenia na biskupa. Kilku ordynariuszy diecezji w metropolii kijowskiej było już w podeszłym wieku. Dotyczyło to zwłaszcza władyki włodzimiersko-brzeskiego Wassiana II. Według metropolity Józefa Sołtana najlepszym kandydatem na stanowisko ordynariusza tej diecezji był ihumen Pafnucy. Ihumen supraski został więc biskupem „,nareczennym", ale godność swoją objął po śmierci władyki Wassiana II. Jego kandydaturę poparł nie tylko metropolita Józef, ale i świeckie elity prawosławne - książę Fiodor Jarosławowicz, książę Konstanty Ostrogski, księżna Helena Iwanówna i Aleksander Chodkiewicz ${ }^{52}$.

Po wyborze ihumena Pafnucego na biskupa włodzimiersko-brzeskiego 15 października 1510 roku metropolita Józef Sołtan nadał nowy „ustaw” - regułę klasztorną, którą powinni przestrzegać zakonnicy ${ }^{53}$. Zbieżność czasowa owych dwóch wydarzeń pokazuje, że obaj hierarchowie pragnęli zachować kontrolę nad rozwijającym się monasterem. Nowy ihumen w świetle nadanego „ustawu” nie miał już takich praw jak Pafnucy Sieheń. Ihumen został zobowiązany do nieopuszczania monasteru bez szczególnej przyczyny. Na spotkanie z królem czy ktitorem ihumen mógł wyjechać jedynie w towarzystwie dwóch zakonników wybranych przez starszyznę monasterską. Po załatwieniu spraw przełożony powinien bez zwłoki wrócić do monasteru. Sprawy gospodarcze ihumen miał rozstrzygać razem z klasztornym ekonomem oraz wybranymi do tego zadania mnichami. Wszelkie pieniądze wpływające do monasteru miały być przechowywane przez ekonoma i wyznaczonych mnichów w skarbcu cerkiewnym. Oni też powinni prowadzić szczegółowy rejestr dochodów i wydatków monasterskich i składać coroczne sprawozdanie ihumenowi o stanie finansów. Ihumen powinien nadzorować zachowanie braci, którzy mieli żyć w „miłości i posłu-

supraskich, s. 57, 139; Николай (Далматов), Супрасльский Благовешенский монастырь, с. 24-27.

50 Митрополит Макарий (Булгаков), История Русской Церкви, т. IX, с. 168; Акты исторические собранные и изданные Археографической комиссиею..., т. I, Санкт-Петербург 1841, s. 524-529. Na ten przywilej patriarszy powoływał się metropolita kijowski Józef Sołtan w 1514 r. АСД, т. IX, s. 5. Oryginał jest przechowywany w Archiwum Państwowym na Wawelu, Archiwum Młynowskie Chodkiewiczów (dalej: AP w Krakowie, AMCh), nr 36; „Вестник Западной России”, Вильно 1867, г. V, кн. VII, т. I, s. 15; Summariusz dokumentów do dóbr supraskich, s. 57, 139 .

51 А. Белецкий, Митрополитъ Іосифъ II Солтанъ и отношение его къ Супрасльскому монастырю, Вильна 1899, с. 16-17; A. Mironowicz, O poczatkach monasteru supraskiego i jego fundatorach, s. 34-35. 52 A. Mironowicz, Sobory wileńskie 1509 i 1514 roku, [w:] Synody Cerkwi prawosławnej w I Rzeczypospolitej, pod red. Marzanny Kuczyńskiej i Urszuli Pawluczuk, „Latopisy Akademii Supraskiej”, vol. 5, Białystok 2014, s. 71-82.

$53 \mathrm{Na}$ temat reguł życia wewnętrznego w monasterach, por:: Древнерусские иноческие уставы, (Русский типик) подг. текста Т. В. Суздальцева, Москва 2001; Монашество и монастыри в России XI-ХХ вв: исторические очерки, отв. ред. Н. В. Синицына, Москва 2002. 
szeństwie". Wszelkie naruszenie zasad życia klasztornego było napominane, a gdy owe napomnienia nie skutkowały, osobę taką usuwano $\mathrm{z}$ monasteru ${ }^{54}$.

„Ustaw” określał rolę monasteru w ówczesnej Cerkwi. Metropolita pragnął, ażeby klasztor poprzez surową regułę życia wewnętrznego wzbudzał respekt wśród prawosławnych i innowierców. Mnisi mieli za zadanie umacniać wiarę wśród prawosławnych mieszkańców zachodnich obszarów Wielkiego Księstwa Litewskiego, a wśród innowierców rozwijać szacunek wobec Cerkwi. W „ustawie” zwraca uwagę zapis odnośnie celi zakonnej. Mogły w niej być przechowywane jedynie ubrania, księgi i rzeczy niezbędne do pracy monasterskiej. Metropolita Józef znał skład osobowy zgromadzenia i wiedział, że wśród mnichów znajduje się wiele osób wykształconych - umiejących czytać i pisać, kopiować i interpretować teksty liturgiczne.

Powstaje pytanie: po co nadano klasztorowi nowy statut, skoro monaster posiadał go już wcześniej, a patriarcha konstantynopolitański Joachim zatwierdził regułę specjalnym tomosem z 1505 roku? Nowy statut ustalał zasady życia wspólnotowego na terenie nowej lokalizacji monasteru. Wcześniejsze regulacje odnosiły się do życia eremickiego, które mnisi prowadzili w okolicy Gródka. Należy zwrócić uwagę na surowość pierwszej reguły życia monastycznego w Supraślu. Wielu mnichów przeszło wszystkie stopnie życia zakonnego i stało się schimnikami. Wśród nich było kilku otszelników (pustelników), żyjących w osobnych leśnych celach poza monasterem. Zmiana lokalizacji klasztoru spowodowała nie tylko zmianę charakteru życia monastycznego $\mathrm{z}$ eremickiego (anachoretycznego) na wspólnotowe (cenobityczne), ale skutkowała również odejściem części mnichów do Lawry Kijowsko-Pieczerskiej i na św. Górę Athos.

„Ustaw” metropolity Józefa z 15 października 1510 roku nic nie wspominał o wybudowanej murowanej cerkwi. Oznacza to, że dopiero po tej dacie rozpoczęto bądź kontynuowano budowę cerkwi Zwiastowania NMP. Nie wiadomo, czy na terenie Suchego Hrudu znajdowały się wówczas inne budowle. Według Aleksego Bieleckiego, który zapoznał się z oryginalnym dokumentem „ustawu”, nie było w nim żadnej informacji o świątyniach, a dopiero

\footnotetext{
54 Według tego „ustawu” bracia powinni przebywać w monasterze, a ich wyjścia w sprawach klasztornych na zewnątrz mogły się dokonać jedynie za zgodą ihumena, w towarzystwie dwóch lub trzech mnichów. Mnisi nie mogli mieć własnych rzeczy (ubrania, jedzenia, pościeli). Wszystko zakonnik otrzymywał od monasteru. Nawet ihumen jadł w sali jadalnej (trapezie), z wyjątkiem nadzwyczajnych okoliczności. Ihumen i hieromnisi mogli nosić habity (rasy) z czeskiego sukna, pozostali zaś ze zwykłego. W celach zakonnych mogło znajdować się jedynie ubranie i książki. Zakonnicy w poniedziałek, środę i piątek jedli tylko raz dziennie. Głównym składnikiem pożywienia w te dni był chleb i woda. We wtorek mnisi spożywali pokarm dwukrotnie w dzień, ale bez oleju, a w czwartek z olejem. Napojami mnichów była woda i kwas. Do monasteru przyjmowano wszystkich prawosławnych mężczyzn, ale zaliczenie do grona braci zakonnej następowało dopiero po trzy- lub sześciomiesięcznym nowicjacie. Mnisi z innych klasztorów, za zgodą ihumena, mogli wstąpić do wspólnoty po trzydniowym pobycie w monasterze. Dzieci nie przyjmowano do monasteru, a kobietom było zabronione wchodzenie na jego teren. АСД, т. IX, с. 16-19; „Вестник Западной России”, кн. 8, т. III, отд. 2, Вильно 1866 , c. $1-6$.
}

do późniejszej kopii wstawiono odpowiedni zapis o nich ${ }^{55}$. Przywilej metropolity rozpoczynał się od sformułowania, że Aleksander Chodkiewicz postanowił „доброю волею и накладом сооружити монастырь иноком мнишскаго общаго равножительства" w dobrach swoich na uroczysku między dwiema rzekami Grabówka i Berezówka. Nastąpiło to latem 1510 roku za panowania króla Zygmunta Starego, przy metropolicie kijowskim Józefie Sołtanie, w dobrach rodowych Aleksandra Chodkiewicza.

Z tym opisem koresponduje wstawione do „ustawu” monasterskiego opowiadanie o powstaniu świątyń klasztornych: „И наперве соружена бысть церковь невелика, теплая, во имя святаго Іоанна Богослова, и трапеза на прихожденіе братіи. И освещена бысть тая церковь преосвященным митрополитом Кіевским и всея Руси Іосифом, на Обретеніе святыя главы Предтечи и Крестителя Іоанна, мая 25 день, индикт 14. И потом соружена бысть великая церква Пречистыя Богоматере, Честнаго Ея Благовещенія, с приделы святых мученик Бориса и Глеба, нареченных в святом крещеніи Романа и Давида, и святых преподобных отец Печерских Антонія и Феодосія. Сія же святыя Божія церкви освященны бышя преосвященным митрополитом Кіевским и всея Руси. В честь и хвалу и славу и поклоненіе и пеніе Вседержительной, Единосущней Троицы Отцу и Сыну и Святому Духу, Единому Богу, сбранным, живущим в сей святей Лавре, посполито всему, еже о Христе братству обще вкупе живущим на отпущеніе грехов и на спасеніе душам, а отшедшим от телес душам в наследіе царства небеснаго, его же Господь Бог сподобит и нас всех получити о Христе Іисусе Господе нашем, Ему же слава в веки, аминь".

$\mathrm{W}$ tej relacji znajduje się kolejna istotna informacja: „И помовивши о том с сыном нашим паном Александром Ивановичом Ходкевичом и с всим, еже о Христе братсвом, хотячи утвержденіе мети общему жительству по уставу божественнаго писанія, добровольне единоумно завет положихом"56. Dalej następuje podanie „ustawu” monasterskiego. Zwróćmy uwagę na fakty podane we wstawionym, dopisanym później fragmencie, przed treścią podanych reguł klasztornych. Przywilej metropolity Józefa został rzekomo wystawiony 15 października 1510 roku, a więc nie mógł podawać faktów po tej dacie. Między innymi w dokumencie mówi się o wyświęceniu cerkwi św. Jana Teologa 25 maja, indykta 14, to jest 25 maja 1511 roku. Przypomnę, że indykta rozpoczynają się 1 września, a kończą się 31 sierpnia następnego roku. Jakim więc sposobem metropolita mógł napisać co się wydarzy 25 maja 1511 roku? W dokumencie mówi się о „живущим" w Ławrze, a więc tam, gdzie monaster funkcjonuje, a nie dopiero się buduje. W „ustawie” metropolita Józef Sołtan pisze o sobie w pierwszej osobie, a we fragmencie opowieści o powstaniu cerkwi klasztornych mówi się o metropolicie w osobie trzeciej. $\mathrm{Z}$ dopisku tego wynika,

\footnotetext{
55 А. Белецкий, Митрополить Іосифъ II Солтанъ и отношение его къ Супрасльскому монастырю, с. 25.

56 АСД, т. IX, с. 17; A. Mironowicz, Powstanie monasteru supraskiego, s. 25 .
} 
że nowa cerkiew św. Jana Teologa na uroczysku Suchy Hrud została wyświęcona 25 maja 1511 roku. Wszystko staje się zrozumiałe, kiedy przyjmiemy, że do oryginalnego dokumentu - przywileju Józefa Sołtana z 1510 roku, któryś z mnichów, w późniejszym czasie, dodał informację o budowie świątyń klasztornych. Przywołując tu zapisy z Субботника или Поминника można też wnioskować, że niektóre informacje o cerkwiach dotyczą pierwotnej lokalizacji monasteru w Gródku. Mnisi wielokrotnie dokonywali dopisków do oryginalnych dokumentów w różnych polach. Pewną podpowiedzią, kiedy pobudowano monaster na uroczysku Suchy Hrud może być przywilej metropolity Józefa Sołtana dany klasztorowi 5 lutego 1514 roku, gdzie mówi się o supraskim monasterze, który „stał nowo" i nazywa się go „новосооружоным”57.

Wynika z tego, że ihumen Pafnucy Sieheń rozpoczął budowę murowanej cerkwi Zwiastowania NMP, ale jej nie zakończył. Jest wielce prawdopodobne, że to pierwszy ihumen supraski wybudował drewnianą cerkiew św. Jana Teologa, która została wyświęcona 25 maja 1511 roku. Jako „nareczenny” biskup włodzimiersko-brzeski od tego wydarzenia nie przebywał już w monasterze, lecz prawdopodobnie w Brześciu. Władyka Pafnucy pozostawił monaster w bardzo dobrym stanie duchowym i materialnym. Kilkudziesięciu mnichów z dużym stażem życia monastycznego gwarantowało stabilność ośrodka zakonnego. Szeroko podjęte inwestycje, zgromadzenie bogatej kolekcji ksiąg rękopiśmiennych, rozpoczęcie budowy cerkwi Zwiastowania NMP były możliwe do zrealizowania dzięki pozyskaniu przez Pafnucego licznych nadań i zapisów od ówczesnych elit prawosławnych, takich jak księżna Helena, Aleksander Chodkiewicz - marszałek hospodarski (1506-1509), Iwan Sapieha - wojewoda podlaski, czy Józef Sołtan - metropolita kijowski ${ }^{58}$. Pierwszy ihumen monasteru supraskiego nie zapomniał o swym klasztorze pełniąc obowiązki biskupa włodzimiersko-brzeskiego i łucko-ostrogskiego ${ }^{59}$. O jego bliskich relacjach świadczą nadesłane przez niego do biblioteki klasztornej rękopisy i liczne wpisy do supraskiego Субботника или Поминника imion osób pochodzących z Wołynia i Polesia.

Monaster supraski, jeden z największych prawosławnych ośrodków zakonnych na terenie Wielkiego Księstwa Litewskiego w XVI w., utrzymywał ścisłe kontakty z podobnymi centrami w kraju i zagranicą. Bliskie relacje mo-

Biblioteka Muzeum Narodowego im. Czartoryskich w Krakowie, Zbiór dokumentów pergaminowych, nr 76, (MNK 541/8), k. 1; Николай (Далматов), Супрасльский Благовещенский монастырь, с. 28. «Бо тая обитель стала на нове, предъ тымъ издавна съ того месца митрополитомъ продкомъ нашимъ никакихъ пожитковъ небывало». $A B A K$, Акты Гродненского земского суда, т. I, Вильно 1865, с. 38; „Вестник Западной России", г. VIII, кн. 2, т. I, отд. 2, Вильно 1870, с. 19-24.

58 Николай (Далматов), Супрасльский Благовещенский монастырь, c. 62. O nadaniach księżnej Heleny monasterowi supraskiemu por.: Prawa i przywileje miasta i dóbr ziemskich Zabludów XV-XVIII w., s. 42, przyp. 4.

59 A. Mironowicz, Nieznane losy pierwszych ihumenów supraskich, s. $41-59,84-98$. nasteru z Kijowem, Słuckiem, Wilnem, Moskwą, Serbią, Wołoszczyzną, Bułgarią i ze św. Górą Athos pozwoliły na skoncentrowanie w nim dorobku kulturowego wielu narodów słowiańskich. Monaster supraski zajmuje niekwestionowane miejsce w historii Kościoła prawosławnego, regionu i kultury wielu narodów. Ten najbardziej wysunięty na zachód prawosławny ośrodek klasztorny przekształcił się w drugiej połowie XVI w. w centrum kulturowe o znaczeniu ogólnosłowiańskim. Trudno bowiem wskazać inny ośrodek, w którym w takim zakresie skoncentrowane zostały najlepsze osiągnięcia różnych dziedzin kultury i w którym tak intensywnie przejawiały się kontakty z kulturą innych narodów słowiańskich, a najgłębsze i stare tradycje weszły organicznie w życie następnych wieków. Oddziaływanie kultur narodów wschodniosłowiańskich i bałkańskich uwidoczniło się na terenie monasteru w architekturze i malarstwie ikonograficznym, wystroju i wyposażeniu świątyń oraz w zbiorach biblioteki klasztornej.

W bibliotece znalazły liczne przykłady na to, że monaster supraski utrzymywał bliskie kontakty z ośrodkami serbskimi i bułgarskimi ${ }^{60}$. Tradycja powiązań ośrodków prawosławnych z Wielkiego Księstwa Litewskiego z Serbią i Bułgarią sięgała 1415 roku, kiedy to metropolitą kijowskim został Grzegorz Camblak ${ }^{61}$. Z przepisanych w Supraślu rękopisów dużym zainteresowaniem cieszyły się słowa pochwalne Klimenta Ochridskiego, Поучение Дорофея и з житием Саввы Освещенного и Иоана Злотоустого ${ }^{62}$ czy pisma metropolity Grzegorza Camblaka (Похвала трем отрокам, Толкование о кубке Соломона і Житие славянского святого), a zwłaszcza jego kazania świąteczne: На рождество Иоанна Предтечи, На Успение i Похвальное слово Евфимию Тырновскомуб. ${ }^{63}$. Księgi te znajdowały się w bibliotece klasztornej już w I połowie XVI w. ${ }^{64}$ Pisma Grzegorza Camblaka Похвальное слово

60 Szerzej por.: А. И. Рогов, Литературные связи Белоруссии с балканскими странами в XV-XVI вв., [в:] Славянские литературы. VIII Международный съезд славистов, Загреб-Любляна, сентябрь 1978 2. Доклады советской делегации, Москва 1978; A. Naumow, Wiara $i$ historia: $z$ dziejów literatury cerkiewnosłowiańskiej na ziemiach polsko-litewskich, „Krakowsko-Wileńskie Studia Slawistyczne”, t. I, Kraków 1996, s. 45-62; Н. А. Морозова, С. Ю. Темчин, Об изучении церковнославянской письменности Великого княжества Литовского, „Krakowsko-Wileńskie Studia Slawistyczne”, t. II, Kraków 1997, s. 23-35; Odmiennie na ten temat А. А. Турилов, Южнославянские памятники в литературе Литовской и Московской Руси XV-первой половины XVI в.: парадоксы истории и географии културных связей, „Славянский алманах 2000”, 2001, с. 247-285.

${ }_{61}$ T. M. Trajdos, Metropolici Kijowscy Cyprian i Grzegorz Camblak a problemy Cerkwi prawosławnej w państwie polsko-litewskim u schyłku XIV $i$ w pierwszej ćwierci XV w., „Balcanica Posnaniensia. Acta et studia”, t. II, Poznań 1985, s. 211-234.

62 Księga Дорофей и з житием Иоана Злотоустого była już w monasterze przed 1532 r. АСД, т. IX, с. 54; Biblioteka Litewskiej Akademii Nauk, Oddział Rękopisów, f. 19, nr 61; Н. А. Морозова, С. Ю.Темчин, Древнейшие рукописи Супрасльского Благовещенского монастыря (1500-1532 г2.), s. 131.

63 Ф. Н. Добрянский, Описание рукописей Виленской публичной библиотеки, церковнославянских и русских, с. 106-107, 117, 122-123, 224-227.

${ }^{64}$ Biblioteka Litewskiej Akademii Nauk, Oddział Rękopisów, f. 19, nr-y: 61, 62; Н. А. Морозова, С. Ю.Темчин, Древнейшие рукописи Супрасльского Благовещенского монастыря (1500-1532 г2.), s. 131. 
митрополиту Киприану і Похвальное слово Евфимию Тырновскому zawierają terminologię cerkiewną i słownictwo serbskie i bułgarskie.

Potwierdzeniem związków z ośrodkami serbskimi było zamieszczenie w Kodeksie z XVI wieku żywotu św. Sawy Serbskiego, a w Mineji służebnej na miesiąc luty (poł. XVI w.) oficjum ku czci św. Symeona Serbskiego ${ }^{65}$. Obok oficjum ku czci św. Symeona Serbskiego jeden z jego supraskich czytelników napisał: „По рассуждении иску с нинейшых не празнуется сей Симеон число 13 дня” i dalej w innym miejscu: „св. Симеона Сербского не празнуется". Zapis ten sugeruje, że nie wszyscy w monasterze akceptowali kult świętego serbskiego. Kult św. Symeona cieszył się dużą popularnością na Rusi Moskiewskiej, nie był natomiast popularny w Wielkim Księstwie Litewskim. Powodem takiej postawy była sama postać świętego, który znany był z działalności przeciwko arianom $^{66}$. W XVI wieku arianizm był rozpowszechniony w Wielkim Księstwie Litewskim i zapewne nie chciano lansować świętego serbskiego, znanego przeciwnika tego wyznania. W Mineji na październik (poł. XVI w.) znajduje się oficjum ku czci św. Arseniusza Serbskiego z charakterystycznym dopiskiem: „в сей же день святаго Уроша караля ктитора места сего, паче же новые сей церкве”. Uwaga ta przepisana została z serbskiego rękopisu, pochodzącego zapewne z cerkwi Zaśnięcia NMP w Nerodimla na Kosowym Polu lub monasteru Narodzenia Bogurodzicy w Skopje ${ }^{67}$. Kanonizowany król Stefan IV Urosz Duszan (1308-1355) był fundatorem obu ośrodków cerkiewnych. Rękopisy, które trafiały do monasteru supraskiego, zatracały swe południowosłowiańskie pochodzenie i przyjmowały wersję staroruską ${ }^{68}$. W takiej też wersji przepisane, a często przeredagowane, były rozpowszechniane na ziemiach Wielkiego Księstwa Litewskiego i Korony ${ }^{69}$.

Przykładów oddziaływania literatury bałkańskiej w rękopisach supraskich można wskazać więcej. Np. «Книга Великого Василия Кесарийского, новописанная» zе słowo Jerzego (Georgiosa) Pizydesa: «Похвала Богу о сотворении всея твари» (k. 294v-312) ${ }^{70}$. Rękopisy są na-

Ф. Н. Добрянский, Описание рукописей Виленской публичной библиотеки, иерковнославянских и русских, с. 286.

66 Tamże, c. 286.

67 А. И. Рогов, Супрасль как один из центров.., с. 330-331; С. П. Обнорский, К литературной истории Хождения Арсения Солунского, „Известия отделения русского языка и словесности Академии наук”, т. ХІХ, кн. 3, Москва 1914, с. 196-205.

68 С. Темчин, О хиландарском проишождении афонско-сербского оригинала супрасльских рукописных служсебных нибей середины XVI

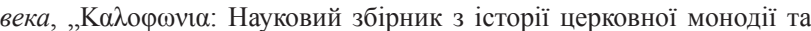
гимнографіï”, ч. VI, Львів 2012, с. 15-20; Przedruk w: С. Ю Темчин, Афоно-сербский оригинал супрасльского рукописного комплекта служебных миней середины XVI в. и его дальнейшая судьба, „Афон и славянский мир. Сборник”, нр. 1, ред. Ж. Л Левшина, Афон 2014, c. $184-192$.

${ }^{69}$ Historica Russiae Monumenta, ab A. I. Turgenevio, Petropoli 1841, vol. 1, p. 123-127; A. Mironowicz, Zwiqzki literackie Kijowa..., s. 541$-542$

70 Ф. Добрянский, Описание рукописей Виленской публичной библиотеки, церковно-славянских и русских, s. 68. macalnym dowodem na południowo-słowiański wpływ na piśmiennictwo ruskie ${ }^{71}$.

W kodeksie, przechowywanym w bibliotece monasteru kijowskiego św. Michała, znajdowało się osiem utworów supraskich z XVI w ${ }^{72}$. Większość z nich potwierdzała bliskie związki monasteru supraskiego ze św. Górą Athos i ośrodkami bałkańskimi w tym i z serbskimi. Były to:

1) List do nieznanego z imienia arcybiskupa łacińskiego z $1511 r^{73}$

2) Postanie węgierskiego króla Janusza do mnichów św. Góry Athos z $1534 r^{74}$

3) Odpowiedź mnichów athoskich na posłanie króla węgierskiego Jana Zapolyi z $1534 r^{75}$

С. Темчин, Послесловие к четьему „Апостолу” 1183 года монаха Исайи в супрасльскогм списке Матвея Десятого 1502-1507 года, „Krakowsko-Wileńskie Studia Slawistyczne”, t. VI, Kraków 2011, s. 131. 72 Н. И. Петров, Супрасльский монастырь как защитник православия в XVI и в начале XVII века, „Виленский календарь на 1896 год”, Вильно 1895, с. 164-179; А. Mironowicz, Zwiazki monasteru supraskiego ze Święta Górą Athos w XVI wieku, s. 122-134.

${ }_{73}$ W rejestrze książka ta występuje jako „Книжка на латину”, $А С Д$, т. IX, c. 54. Posłanie składa się z dwóch części: 1) pierwsza przedstawia kazania św. Ojców Kościoła, wypisy z Ewangelii, posłania apostolskie oraz naukę o pochodzeniu Ducha Świętego od Boga Ojca; 2) druga stanowi polemikę z nauką Kościoła katolickiego o prymacie papieskim i ukazuje odejście Cerkwi rzymskiej od postanowień siedmiu soborów powszechnych. Utwór ma charakter odpowiedzi na list arcybiskupa katolickiego. Według N. Petrowa, odpowiedź polemiczna została napisana przez mnicha supraskiego i nawiązywała do listu arcybiskupa, pragnącego pozyskać do unii Aleksandra Chodkiewicza (Н. И. Петров, Супрасльский монастырь..., с. 169-170). Ktitor monasteru polecił ihumenowi Kalistowi rozpatrzenie posłania i przygotowanie na nie odpowiedzi. Arcybiskupem, starającym się o pozyskanie Chodkiewicza do unii był arcybiskup gnieźnieński Jan Łaski (1510-1531), który na soborze laterańskim przedstawił Posłanie o bładzeniu narodu ruskiego. Por.: Центральная научная библиотека Академии наук Украины в Киеве (dalej: ЦНБ АНУ), 475п/1656, л. 1-21; Historica Russiae Monumenta, vol. 1, p. 123-127. Autor traktatu supraskiego doskonale opisał prawosławne pojmowanie pochodzenia Św. Ducha od Boga Ojca i wskazał błędy w nauce Kościoła łacińskiego o apostole Piotrze jako namiestniku Chrystusa i o przywództwie papieża. А. Белецкий, Митрополить Ioсифъ II Солтанъ и отношение его къ Супрасльскому монастырю, с. 34; A. Mironowicz, Zwiazki literackie Kijowa..., s. 541-542; tenże, Życie monastyczne na Podlasiu, s. 15; tenże, Literatura bizantyjska w Kościele prawosławnym na terenie Wielkiego Księstwa Litewskiego w XVI wieku, „Търновска Книжовна Школа”, Търново и идеята за Християнския Универсализъм XII-XV век, т. IX, Велико Търново 2011, с. 692-704.

74 Posłanie wegierskiego króla Janusza do mnichów św. Góry Athos z 1534 r. ЦНБ АНУ, 475 п/1656, л. 21v-26; Н. И. Петров, Супрасльский монастырь..., с. 170-171; A. Mironowicz, Zwiazki literackie Kijowa..., s. 541, przyp. 25; tenże, Życie monastyczne na Podlasiu, s. 15; tenże, Literatura bizantyjska $w$ Kościele prawosławnym na terenie Wielkiego Księstwa Litewskiego w XVI wieku, „Białoruskie Zeszyty Historyczne”, nr 31, Białystok 2009, s. 146-147.

75 Utwór stanowi polemikę z hasłami reformacyjnymi. Odpowiedź mnichów athoskich była reakcją na rozwój luteranizmu na Węgrzech (1534 r.). Jan Zapolya (do niego była skierowana Odpowiedź mnichów athoskich) został królem węgierskim (1526-1540) obranym przez część magnatów po śmierci Ludwika II Węgierskiego (1526). Konkurentem do korony był Ferdynand I Habsburg. Obaj pretendenci doszli do porozumienia w 1538 r. Zapolya otrzymał Siedmiogród i część Węgier oraz dożywotnio - tytuł królewski. Jako król węgierski pragnął wykorzystać niektóre rozwiązania organizacyjne i obrzędowe Kościołów prawosławnego i luterańskiego do naprawy Kościoła katolickiego. W tym celu nawiązał kontakty z mnichami athoskimi, prosząc ich o ukazanie różnic między katolicyzmem a prawosławiem i luteranizmem, a także o opinię na temat projektu zwołania na terytorium Węgier soboru hierarchów Kościoła wschodniego i zachodniego. Mnisi greccy wykazali odejścia teologiczne Kościoła 
4) Повесть о разорении Афона латиномудрствующими в 1276 году, przepisana w monasterze supraskim W $1546 \mathrm{r}^{76}$

5) Rozmowa chrześcijanina z Żydem o wierze $i$ ikonach $^{77}$

6) Posłanie do Łacinników z $1581 \mathrm{r}^{78}$

7) Сказание на богомерзскую, на поганую латину,

katolickiego od postanowień siedmiu soborów powszechnych i różnice dogmatyczne między wyznaniami chrześcijańskimi. Ta część „posłania” była wielokrotnie wykorzystywana przez mnichów supraskich w utworach polemicznych. ЦНБ АНУ, 475 п/1656, л. 26v-96; А. Mironowicz, Zwiazki literackie Kijowa..., s. 541, przyp. 26; tenże, Życie monastyczne na Podlasiu, s. 15; tenże, Literatura bizantyjska ..., s. 147.

16 Повесть о разорении Афона латиномудрствуюшими в 1276 году и о восстановлении Ксиропотамской обители императором Андроником trafił do Supraśla ze św. Góry Athos. Por.: Н. И. Петров, Западнорусские полемические сочинения XVI века, „Труды Киевской Духовной Академии”, 1894, № 2, с. 154-186. Inny utwór opowiada o wydarzeniach, które miały miejsce w monasterze Kseropotamou na św. Górze Athos. W okresie rządów cesarza bizantyjskiego Romana (10281034), w cerkwi sobornej monasteru kseropotamskiego w dzień 40 męczenników (9 marca) corocznie wyrastał grzyb o czterdziestu zakończeniach. W tejże świątyni, za panowania imperatora Michała VIII Paleologa (1258-1282), ogłoszono unię lyońską z Rzymem. Wydarzenie to miało miejsce w $1276 \mathrm{r}$. Po ogłoszeniu unii grzyb przestał rosnąć, a cerkiew uległa zniszczeniu podczas trzęsienia ziemi. Odbudowano ją za panowania cesarza Andronika II (1282-1328). Д. М Буланин, Чудо с грибом в Ксиропотаме,w: Словарь книжников и книжности Древней Руси. вып. 2: (Вторая половина XIV-XVI в.). ч. III: Библиографические дополнения. Приложение, ред. Д. М Буланин , Санкт-Петербург 2012, с. 734738. Utwór Повесть о разорении Афона zawierał charakterystyczny dopisek: „Сия повесть принесена бе из Святое горы Калугери у монастырь Супрясльскии в лето от создания миру 7054-е [1546] и в то же лето в сию книгу вписана, а когда она содеашеся перед концем выображена суть, еже о обители Ксиропотамстеи, иже в святой горе сбысться от латиномудрствующих (...)”. Библиотека Российской академии наук в Санкт-Петербурге, ф. П. Доброхотова, № 31, л. 41. Повесть opowiada o zgubnych dla Kościoła prawosławnego następstwach zajęcia św. Góry Athos przez Lacinników i powołaniu do życia Cesarstwa Łacińskiego (1204-1261). Opowieść miała być przestrogą tym wszystkim, którzy zdecydowali się porzucić prawosławie. Utwór ten był wielokrotnie kopiowany $\mathrm{w}$ monasterze supraskim i rozpowszechniany w innych ośrodkach zakonnych. Por.: Н. И. Петров, Западнорусские полемические сочинения XVI века, с. 154-186; A. Mironowicz, Zwiazki literackie Kijowa..., s. 541, przyp. 27; tenże, Życie monastyczne na Podlasiu, s. 15; tenże, Literatura bizantyjska ..., s. 147; Д. М Буланин, Чудо с грибом в Ксиропотаме, w: Словарь книжников и книжности Древней Руси., с. 734-738. W monasterze supraskim powstały też inne utwory polemiczne w oparciu o oryginały sprowadzone ze św. Góry Athos. Por.: Prawdopodobnie w oparciu o oryginały greckie w Supraślu zostały spisane 16 слов Григория Богослова с толкованиями Никиты Ираклийского oraz Сборник składający się z tekstów religijnych przepisywanych przez wielu autorów. Biblioteka Litewskiej Akademii Nauk, Oddział Rękopisów, f. 19, nr-y: 57, 103.

77 ЦНБ АНУ, 475 п/1656, л. 198-201; В. Є. Зема, Полеміко-догматичні збірки XVI- початку XVII cm. „Українсьий історичний журнал”, нр. 5, 2001, с. 43-74; A. Mironowicz, Zwiazki literackie Kijowa..., s. 542; tenże, Życie monastyczne na Podlasiu, s. 16; tenże, Literatura bizantyjska ..., s. 145.

78 Posłanie do Łacinników... z 1581 r. było skierowane przeciwko pismom jezuity Piotra Skargi, przygotowującego grunt pod unię kościelną. Utwór stanowił odpowiedź na prace Skargi „O jedności Cerkwi Bożej...” wydanej w 1577 r. W Posłaniu supraskim odnajdujemy ostrą polemikę z dogmatami Kościoła katolickiego. ЦНБ АНУ, 475 п/1656, л. 157-169; Н. И. Петров, Супрасльский монастырь..., с. 171-173; tenże, Западнорусские полемические сочинения XVI века, 1894, № 3, с. 349-380; А. Mironowicz, Zwiazki literackie Kijowa..., s. 542; tenże, Życie monastyczne na Podlasiu, s. 16; tenże, Literatura bizantyjska ..., s. 146, przyp. 12. которую папежи, хто в них вымыслили в их поганой вере . $^{79}$.

8) utwór Новоизложенное поучение во Литвании нариияаемым Логофетом ${ }^{80}$.

Niektóre fragmenty pierwszych pięciu utworów powtarzają się w drugiej redakcji, złożonej w monasterze supraskim w 1578 r. i przepisanej w 1580 r. ${ }^{81}$ Zawierają one ostrą polemikę z naukami protestantyzmu, judaizmu, katolicyzmu i islamu. Popularne było na ziemiach Wielkiego Księstwa Litewskiego powstałe w Supraślu (1570) Cnuсание против лютров, wymierzone przeciwko zwolennikom reformacji ${ }^{82}$. Jego kopistą był tamtejszy „священноинок" (zakonnik ze święceniami kapłańskimi) Eustachy ${ }^{83}$. Mnich Eustachy przywiózł do monasteru pergaminową Ewangelię z XIII wieku i przechowywał ją w swej celi, kiedy był jeszcze archidiakonem ${ }^{84}$.

Innym przykładem kontaktów mnichów supraskich ze serbskimi ośrodkami monastycznymi była działalność micha Arseniusza. W 1530 r. mnich supraski Arseniusz, były duchowny Aleksy, skopiował pracę św. Jana Klimaka Лествиия. Книга Лествица в полдесть znajdowała się w monasterze przed 1530 r. Rękopis ten był dwukrotnie kopiowany w połowie XVI wieku ${ }^{85}$. W wyniku powsta-

79 Сказание на богомерзскую, на поганую латину... spisane po 1586 r. było odpowiedzią mnichów supraskich na książkę Piotra Skargi. Oba utwory (Сказание і Послание) powstały za archimandrii Tymoteusza Złoby (1575-1589), gorliwego obrońcy praw Cerkwi prawosławnej. ЦНБ АНУ, 475п/1656, л. 205-208; Н. И. Петров, Супрасльский монаcmblpь..., c. 173-174; A. Mironowicz, Zwiazki literackie Kijowa..., s. 542; tenże, Życie monastyczne na Podlasiu, s. 16; tenże, Literatura bizantyjska ..., s. 14, przyp. 13. Na wcześniejsze lata powstania tego utworu zrodzili uwage: Ф. Покровский, Послание Василия, пресвитера Никольского из дольней Руси об исхождении Святого Духа, «Известия Отделения русского языка и словесности", 1908, т. СXII, кн. 3, прл. 1, с. 86. a ostatnio В. Є. Зема, Полеміко-догматичні збірки XVI- початку XVII cm., c. 56-74.

80 Н. И. Петров, Супрасльский монастырь..., с. 174-175.

81 А. Попов, Обличительные списания против жидов и латинян. (По рукописи имп. Публичной библиотеки 1580 г.), „Чтения в Императорском Обществе истории и древностей российских", Москва 1879, кн. 1, с. 1-41; Ю. А. Лабынцев,. Об одном важном спорном моменте в судьбах белорусской православной культуры XVI столетия в связи с историей литературной жизни Супрасльского Благовещенского монастыря „Elpis”, R. II (XIII). Zesz. 2 (15), 2000, s. 168; Zbornik klasztoru św. Michała zob.: В. Є. Зема, Полеміко-догматичні збірки XVI- початку XVII cm. с. 58-59.

82 Druk utworu, por.: Русская историческая библиотека, т. XIX, Памятники полемической литературы в Западной Руси. кн. III, СанктПетербург 1903.

83 Zapis tekstów Grzegorza (Grigentiosa) w supraskim zborniku Eustchiusza 1578-1580. Por.: А. Попов, Обличительные списания против жидов и латинян. (По рукописи имп. Публичной библиотеки 1580 г.), c. 1-41; Utwór, zawierający fragmenty posłań o. Artemiusza, doczekał się drugiej redakcji na początku XVII w. A. Mironowicz, Związki literackie Kijowa ..., s. 541-542; A. Naumow, Monaster supraski jako jeden z głównych ośrodków kulturalnych w Rzeczypospolitej, s. 108.

84 A. Mironowicz, Zwiazki literackie Kijowa..., s. 542; tenże, Życie monastyczne na Podlasiu, s. 16; tenże, Literatura bizantyjska ..., s. 146; Zapis Eustachego i inne zapisy na kartach tegoż rękopisu zob.: И. Ю. Бубнов., О. П. Лихачева., В. Ф. Покровская, Пергаменные рукописи библиотеки Академии наук СССР, Леинград 1976, с. 26; Л. Л. Щавиская, Ю. А. Лабынцев, Литература белорусов Польии XV-XIX вв., c. 71 .

85 Biblioteka Litewskiej Akademii Nauk, Oddział Rękopisów, f. 19, nr-y: 246, 247. 
łego konfliktu z archimandrytą Kimbarem, hieromnich Arseniusz zabrał skopiowaną przez siebie pracę św. Jana Klimaka Лествииа i udał się do serbskiego monasteru Chilandar na św. Górze Athos ${ }^{86}$. Nie był to pojedynczy przypadek wywozu rękopisów z biblioteki monasterskiej. Za czasów Sergiusza Kimbara bibliotekę klasztorną opuszczały inne księgi do ośrodków serbskich ${ }^{87}$.

O kontaktach monasteru supraskiego z Serbią świadczy przechowywanie w bibliotece klasztornej najstarszej serbskiej redakcji żywota świętych męczenników wileńskich Antoniego, Joanna i Eustachego. Wersja białoruska żywota trzech męczenników była wersją późniejszą, choć zbliżona była treścią i formą do serbskiej. Potwierdzeniem wpływu kultury południowosłowiańskiej na białoruską było przechowywanie w Supraślu serbskich wersji licznych utworów religijnych np. Хождения Арсения Солунского ${ }^{88}$. Znany był w Supraślu serbski oryginał powieści o Tristanie i Izoldzie. O pochodzeniu rękopisu mówi jego tytuł: Poczinajetsja powiesti o witezach s knig serbskich ${ }^{89}$.

W bibliotece supraskiej znajdowały się również świeckie zabytki literatury starobiałoruskiej, które kształtowały się pod wpływem serbskim i bułgarskim. Życie Aleksandra Wielkiego, wydane w Krakowie w 1550 roku, na ziemiach białoruskich było dopełniane serbskimi dopiskami ${ }^{90}$. Podane przykłady świadczą nie tylko o nietypowości biblioteki supraskiej, ale wskazują na intensywny wpływ serbskiej i bułgarskiej literatury religijnej i świeckiej na ziemie białoruskie. Wpływy serbskie i bułgarskie są widoczne w tematyce, formie i słownictwie tekstów literackich. Serbskie oddziaływanie kulturowe w XVI wieku przypada na okres rozwoju myśli renesansowej, ożywienia intelektualnego społeczeństwa Wielkiego Księstwa Litewskiego. Zbiory biblioteki monasteru supraskiego gromadzone w tym właśnie okresie wskazują, że wpływy serbskie są widoczne w tematyce, formie i słownictwie tekstów literackich.

\footnotetext{
${ }^{86}$ O supraskim pochodzeniu manuskryptu informuje nas zapis na jego 275 stronie. „В лето 7038 (1530), индикта 3, списана бысть книга Лествичникь у монастыри общомь в обители Благовещениа пресвятыя Богородица и святаго Иоанна Богослова иже на реци Супрасле, желаниемь и рукою многогрешнаго инока Арсениа, бывшаго вь мирском житии Алексеа недостоинаго попа". Katalog biblioteki rękopisów monasteru serbskiego Chilandar, nr 185; Д. Богданович, Каталог кирилских рукописа манастира Хиландара, Београд 1978, с. 104; Славянские рукописи Афонских обителей, составили: А. А. Турилов і Л. В. Мошкова, под редакцией А. Э. Н. Тахиоса, Фессалоники 1999, с. 127; Л. Л. Щавиская, Ю. А. Лабынцев, Литература белорусов Польши XV-XIX вв., с. 61, 111, przyp. 36; Н. А. Морозова, С. Ю. Темчин, Древнейшие рукописи Супрасльского Благовещченского монастыря (1500-1532 г2.), s. 133.

87 Biblioteka Uniwersytetu Wileńskiego w Wilnie, Oddział Rękopisów, F58-7, В 1993, k. 4; АСД, т. IX, с. 55; Л. Л. Щавиская, Литературная культура белорусов Подляшья XV-XIX вв., с. 38

88 А. И. Рогов, Супрасль как один из цеентров.., с. 330-331; С. П. Обнорский, К литературной истории Хождения Арсения Солунского, „Известия отделения русского языка и словесности Академии наук”, т. XIX, кн. 3, Москва 1914, с. 196-205.

89 А. И. Рогов, Литературные связи Белоруссии с балканскими странами в XV-XVI вв., с. 190-194.

90 А. И. Рогов, Литературные связи Белоруссии с балканскими странами в $X V$-XVI вв., с. 187-189.
}

Bezpośrednie związki Supraśla z kulturą serbską znajdują potwierdzenie w wystroju wnętrza cerkwi Zwiastowania NMP. Najważniejszą inwestycją klasztorną była wspomniana wyżej cerkiew Zwiastowania NMP. Oryginalność architektury świątyni obronnej Zwiastowania NMP polegała na połączeniu w budownictwie cerkiewnym gotyckiego i bizantyjskiego stylu. Wykonanie tego projektu doprowadziło do rzadko spotykanej rozbudowy sklepienia cerkiewnego, wybudowania czterech miniaturowych wież narożnych i dużej liczby strzelnic w głównym gzymsie. Konstrukcja obiektu przypomina cerkwie obronne św. Zofii w Połocku, Synkowiczach i Małomożejkowie ${ }^{91}$. W architekturze cerkwi Zwiastowania NMP w Supraślu odzwierciedlone zostały wpływy architektury rusko-bizantyjskiej i gotyckiej. Jest to wyjątkowy przykład przenikania się kultury wschodu i zachodu.

Również wystrój wewnętrzny świątyni wskazuje na silne wpływy kulturowe bizantyjsko-ruskie na zachodnie obszary Wielkiego Księstwa Litewskiego. Za archimandrii Sergiusza Kimbara grupa malarzy pod kierunkiem „Serbina Nektarego malarza” ozdobiła wnętrze świątyni freskami ${ }^{92}$. Lakoniczna wzmianka o wypłaceniu należnej malarzowi sumy za pracę przy ikonostasie nie pozwala jednoznacznie określić autorstwa fresków. Często na ziemiach ruskich ci sami mistrzowie byli twórcami ikon i malowideł ściennych. Taka sytuacja zapewne zaistniała w Supraślu. Freski wykonała grupa malarzy pod przewodnictwem ikonopiscy pochodzącego z Serbii. Stanisław Stawicki utożsamia Nektariusza, malującego w Supraślu, $\mathrm{z}$ autorem znanego Typika-Ermini, czyli instrukcji jak wykonywać freski. Według polskiego badacza, pod względem technologicznym freski w wielu szczegółach są zgodne z zaleceniami zawartymi w zapisach Typika-Ermini ${ }^{\prime \prime 93}$. Je-

S. Alexandrowicz, Nowe źródło ikonograficzne do oblężenia Połocka w 1579 r., s. 19-22; И. И. Иодковский, Церкви, приспособленные к обороне в Литве и Литовской Руси, с. 249-311; В. А. Чантурия, История архитектуры Белоруссии, с. 88-90; М. С. Кацєр, Белорусская архитектура, с. 48-52; W. Kochanowski, Pobazyliański zespót architektoniczny $w$ Supraślu, s. 355-396; M. Morelowski, Zarys syntetyczny sztuki wileńskiej od gotyku do neoklasycyzmu z przewodnikiem po zabytkach między Niemnem a Dźwina, Wilno 1939; П. П. Покрышкин, Благовещенская церковь в Супрасльском монастыре, с. 222-237; A. Szyszko-Bogusz, Warowne zabytki architektury kościelnej w Polsce i na Litwie, [w:] Sprawozdanie Komisji do badań sztuki w Polsce, t. IX, z. 3-4, Kraków 1914; J. Maroszek, Pogranicze Litwy i Korony w planach króla Zygmunta Augusta: z historii dziejów realizacji myśli monarszej między Niemnem a Narwia, s. 145-151; R. M. Kunkel, Późnogotyckie cerkwie na zachodnich rubieżach Wielkiego Księstwa Litewskiego, [w:] Sztuka ziem wschodnich Rzeczypospolitej XVI-XVIII w., pod red. Jerzy Lileyko, Lublin 2000, s. 37-53; R. Rokicki, Gotyckie cerkwie na Litwie - inne spojrzenie, „Modus: Prace z historii sztuki”, nr 7, 2006, s. 99-117; A Tichoniuk, Monasterska cerkiew pw. Zwiastowania NMP w Supraślu: studium porównawcze z dziejów architektury sakralnej Wielkiego Księstwa Litewskiego. Praca magisterska napisana pod kierunkiem prof. dr. hab. J. Harasimowicza, Wrocław 2008.

92 Zarządzający monasterem archimandryta Sergiusz Kimbar zaprosił grupę malarzy pod przewodnictwem Nektariusza pochodzącego z Serbii. W Kronice Ławry Supraskiej zapisano pod rokiem 1557: „Сербину Нектарію, маларю, за Деисусец теплое церкви дано коп 6 грошей, а золото церковное. За две святости, што он же робил трех святителей и трех преподобных 9 коп грошей, а золото церковное”. АСД, т. IX, c. 52 .

93 St. Stawicki, Czy Nektarij autor ,,Typika” byt autorem malowidet su- 
żeli przyjąc takie założenie, to autor fresków supraskich był nie tylko malarzem, ale i teoretykiem sztuki, którego zalecenia szeroko stosowano na Bałkanach.

Styl fresków przypomina zabytki serbskiego malarstwa monumentalnego, a zwłaszcza wystrój monasteru Manasii z 1418 r. ${ }^{94}$ Są one jednymi z nielicznych przykładów malarstwa bizantyjskiego na terenach polskich i białoruskich, nie mającymi bezpośredniego lub pośredniego powiązania z Rusią Suzdalską lub tradycyjnymi ośrodkami artystycznymi na Rusi Halicko-Włodzimierskiej. Typ ikonograficzny fresków supraskich posiada analogie w sztuce późnobizantyjskiej z początku XV w. z okresu tzw. „renesansu Paleologów”. Serbska szkoła malarstwa ściennego wywarła poważny wpływ na sąsiednie terytoria ze względu na wielkie bogactwo przedstawień ikonograficznych i przystępność jej uproszczonych form. Miała ona szczególną popularność w środowiskach klasztornych. Była to już druga, po XIII- wiecznej, fala wędrówki serbskich malarzy na północ, na ziemie ruskie. Porównanie fresków supraskich ze znanymi zespołami malowideł serbskich (Ohridu, Kalenicy, Lubostiny, Ravanicy, Manasii) wykazują wspólną tradycję i podobne przedstawienia ${ }^{95}$. Typy niektórych kompozycji figuralnych w dekoracji malarskiej Supraśla były zaczerpnięte z serbskiego malarstwa freskowego. Przykładem wpływów bałkańskich we freskach supraskich może być rozbudowany pejzaż górski $\mathrm{i}$ architektoniczny w tle kompozycji przedstawieni ${ }^{96}$. Freski nawiązywały do serbskiego malarstwa średniowiecznego, znajdującego pod wpływem sztuki zachodnioeuropejskiej, zwłaszcza włoskiej. Detale ubioru i uzbrojenia, tuniki, płaszcze, pasy, formy mieczów i tarcz posiadają cechy bizantyjsko-serbskie. W wystroju malarskim cerkwi Zwiastowania NMP wystąpiło zjawisko łączenia różnych elementów sztuki, jak to miało miejsce na Bałkanach i w Grecji.

Szczegółowy opis kompozycji fresków, z podaniem analogii $\mathrm{z}$ wystrojem ikonograficznym $\mathrm{w}$ innych świątyniach, przedstawili Aleksander Rogow i Aleksander Siemaszko ${ }^{97}$. Za właściwą interpretację przedstawień ikonograficznych należy uznać opisy dokonane przez

praskich?, s. 30-35. Podobny pogląd przedstawił serbski historyk sztuki S. Petkowicz udowadniając, że rękopis instrukcji został sporządzony za panowania Iwana IV Groźnego, a więc w okresie prac nad wystrojem wewnętrznym cerkwi Zwiastowania NMP w Supraślu. Por. С. Петковић, Нектарие Србин, сликар $X V$ в., с. 211-225; przedruk z uzupełnieniami w: Српска уметност у XVI и XVII веку, Београд 1995, (Српска књижевна задруга. Коло 88, књ. 589), s. 255-281 i wersji polskiej: „Rocznik Białostocki”, t. XVI, 1991, s. 293-323). Por. również: A. Siemaszko, Freski z Supraśla: unikatowy zabytek XVI-wiecznego pobizantyńskiego malarstwa ściennego, Białystok 2006, s. 38-48.

94 А. И. Рогов, Фрески Супрасля, с. 345-371.

95 S. Szymański, Freski z Supraśla. Próba rekonstruowania genealogii, „Rocznik Białostocki”, t. XI, 1972, s. 161-181.

${ }_{96}$ Z. Lebiedzińska, Freski z Supraśla. Katalog wystawowy, Kraków 1968, s. 26.

97 А. И. Рогов, Фрески Супрасля, с. 343-358; A. Siemaszko, Malowidta ścienne cerkwi Zwiastowania w Supraślu. Rekonstrukcja programu ikonograficznego, ,Zeszyty Naukowe Uniwersytetu Jagiellońskiego. Prace z historii sztuki", z. 21, Kraków 1996, s. 13-58; tenże, Freski z Supraśla: unikatowy zabytek XVI-wiecznego pobizantyńskiego malarstwa ściennego, Białystok 2006.
Aleksandra Rogowa. Z jego badań wynika, że sceny z życia Chrystusa, Najświętszej Marii Panny, przedstawienie aniołów, apostołów, ewangelistów, proroków, męczenników i świętych ojców Kościoła stanowiły uporządkowany cykl. Rozkład przedstawień i zastosowanie cerkiewnej symboliki wynikały z sytuacji politycznej tego czasu i polemiki z innymi wyznaniami. Postać Chrystusa Pantokratora umieszczona została w zwieńczeniu kopuły, z prawą ręką błogosławiącą, a w lewej trzymającą ewangelię. Ten typ przedstawienia, charakterystyczny dla okresu domongolskigo, był wierną kopią fresku z cerkwi św. Zofii w Nowogrodzie ${ }^{98}$. Od góry znajdował się rząd przedstawień cherubinów i aniołów. Postacie serafinów umieszczono w ramionach gwiazdy utworzonej przez lunety. W lunetach umieszczonych u podstawy kopuły znajdowały się osiem okien. Pod postaciami proroków wykonano ornamentalny pas. Na ścianach ośmiobocznego tamburu (połączeniach między kopułą a dwoma filarami) namalowano postacie Piotra i Pawła z Janem Ewangelistą na wschodniej ścianie tamburu a dwaj Ewangeliści Marek i Mateusz na północno-wschodniej.

Piotr i Paweł nie zostali wyobrażeni w parze, ale razem z Janem Ewangelistą na wschodniej ścianie tamburu w trzecim rzędzie, a dwaj Ewangeliści Marek i Mateusz na północno-wschodniej, a nie ,z drugiej strony”; nie namalowano „między tymi postaciami 17 apostołów i męczenników oddzielonych ornamentalnym pasem", bowiem, rząd Apostołów i ich kilku z ich uczniów w pełnych postaciach stanowił cały trzeci rząd, niżej namalowano rząd świętych w wyobrażeniach do kolan, niżej jeszcze rząd medalionów z przedstawieniami biskupów, tak jak i wyobrażenia symboli Ewangelistów w żagielkach. Pod tymi postaciami umieszczono siedemnastu apostołów i męczenników oddzielonych ornamentalnym pasem. Postacie męczenników z krzyżami w rękach zostały przedstawione w parach, oprócz trzech ostatnich. Poniżej namalowano rząd świętych w wyobrażeniach do kolan, a pod nimi umieszczono rząd medalionów z przedstawieniami biskupów i wyobrażenia symboli Ewangelistów w żagielkach. W rombach sklepień przed ikonostasem wykonano wyobrażenia skrzydlatych cherubinów. W promieniach wywodzących się od nich przedstawiono symbole ewangelistów. W czterech kwadratach znajdowały się postacie Boga, św. Ducha, Zbawiciela-Emmanuela i wielkiej rady aniołów. Przedstawienie wizerunku gołębia naprzeciw Boga-Ojca ukazywało prawosławną naukę o pochodzeniu Ducha Świętego od Boga-Ojca.

Górne części ścian wypełniały przedstawienia z cyklu chrystologicznego i życia Marii Panny (ilustracje hymnu Akathistos). W niższych rzędach przedstawiono świętych ojców, pustelników, zaś na filarach św. rycerzy i męczenników. Taki cykl przedstawień był charakterystyczny dla tradycyjnego malarstwa serbskiego. Rozwój malarstwa serbskiego opierał się głównie o bizantyjskie wzorce i dlatego większość serbskich i bułgarskich malarzy uczyło się sztuki ikonograficznej pod kierunkiem greckich mistrzów.

98 А. И. Рогов, Фрески Супрасля, с. 348. 
Niewielu z nich od początku XVI wieku spotykamy na ziemiach ruskich Wielkiego Księstwa Litewskiego. Jednym z przybyłych z Bałkan malarzy był Nektariusz, twórca fresków i ikonostasu cerkwi Zwiastowania NMP w Supraślu.

Osobne miejsce w kontaktach monasteru supraskiego z serbskim ośrodkami monastycznymi zajmuje św. męczennik Antoni Supraski, który z imieniem Onufry przybył do monasteru supraskiego na początku XVI wieku'99. Po kilku latach pobytu w klasztorze mnich Onufry przyjął wielką schimę z nowym imieniem Antoni i poprosił ihumena Pafnucego o zgodę na udanie się na św. Górę Athos, do krajów okupowanych przez Turków, ażeby oddać życie za Chrystusa. Po przybyciu na Górę Athos mnich Antoni zamieszkał w wieży św. Sawy Serbskiego. Pojawia się problem: gdzie trafił mnich supraski na Świętej Górze Athos? W tym czasie znajdowały się tu trzy wieże św. Sawy Serbskiego. Pierwsza była wzniesiona w starym monasterze ruskim, tam, gdzie przebywał św. Sawa podczas swego pierwszego pobytu na Athosie. Druga wieża znajdowała się w monasterze serbskim Chilandar, a trzecia w stolicy athoskiej republiki - Karies ${ }^{100}$. Według A. Turiłowa mnich

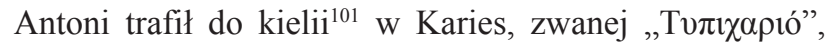
która miała swoją regułę i wieżę ${ }^{102}$. Kielia ta została zbudowana przez św. Sawę, syna króla serbskiego Symeona Neumana (1167-1196), około 1199 r. ${ }^{103}$ Po osiedleniu się św. Sawy w Chilandarze w 1197 r. mnich serbski, dwa lata później, opracował własny typikon, opierając się na regule św. Sawy Jerozolimskiego. Ten typikon obowiązywał w kielii w Karies. Nakładał on surowe zasady życia ascetycznego oparte na poście i modlitwie ${ }^{104}$. Kielia i żyjący

\footnotetext{
99 А. А. Турилов, Житие преподобномученика Антония Супрасльского и славянские жития балканских новомучеников XVI в. (к постановке проблемы), „Hagiographia Slavica”, ed. Herausg. von J. Reinhart, Munchen-Berlin-Wien 2013, („Wiener Slawistischer Almanach. Son-

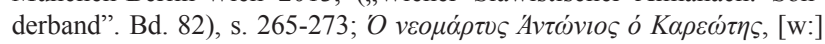

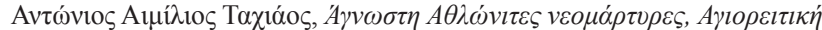

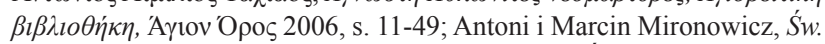
Antoni Supraski, Białystok 2014; A. Mironowicz, Święty Antoni Supra$s k i, ~ „ Е \Lambda \Pi I \Sigma$ ” Czasopismo Katedry Teologii Prawosławnej Uniwersytetu w Białymstoku, R. XVII (XXVIII), z. 29 (42), Białystok 2015, s. 11-24.

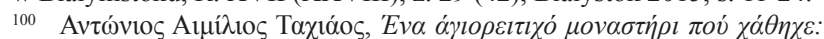

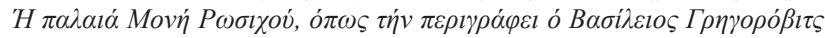

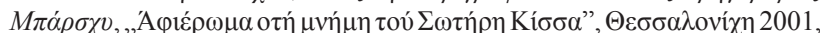
s. 619; С. Ненадовиђ, Осам векова Хиландара. Грађење и грађевине, Београд 1997, с. 21-23; В. Корађ, М. Ковачевиђ, Монастир Хиландар. Конаии и утврђење, Београд 2004, с. 58-62.

101 Kielia, od greckiego słowa cellion, oznacza odizolowany mały budynek z przylegającą kaplicą. Kielia była duchowo, administracyjnie i finansowo zależna od głównego monasteru, pomimo że przebywało w niej nieraz po kilkudziesięciu zakonników.

102 А. А. Турилов, Антоний Супрасльский, с. 680; 'O vєоно́

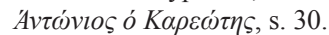

103 Манастир Хиландар, Београд 2000, с. 14-15; Паv. К. Хрฑ́бто, То

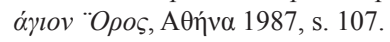

104 Karejski Typikon jest jednym z najważniejszych dokumentów w historii religijnej literatury serbskiej. Na 115 wierszach św. Sawa opracował szczegółowe zasady modlitwy, postu i kultu liturgicznego, które miały być realizowane przez kelliote (mnich, który mieszka w kielii) w Karies. Karejski Typikon był wzorowany na starożytnych zasadach i modlitwach ascetów, którzy żyli na pustyniach w Egipcie, Synaju, Palestynie i Syrii. Karejski Typikon wyraził najbardziej podstawowe zrozumienie i przeko-
}

w niej mnisi cieszyli się dużym autorytetem w republice athoskiej, zwłaszcza w końcu XV i na początku XVI stulecia. Kielię traktowano jako osobny monaster, a mieszkająca w niej wspólnota posiadała własnego przedstawiciela w zgromadzeniu agioryckim ${ }^{105}$. Święty Antoni przybył na św. Górę Athos przed 1507 r. a jego śmierć nastąpiła 17 lutego 1508 r., po męczeństwie św. Jana z Serres, serbskiego miasta w Macedonii ${ }^{106}$.

Żywot św. Antoniego Supraskiego spisano w jednym $\mathrm{z}$ klasztorów athoskich na podstawie opowieści mnichów. Żywot ten był znany mnichom supraskim, albowiem wielu zakonników ze Świętej Góry Athos przebywało w prawosławnych ośrodkach monastycznych na terenie Wielkiego Księstwa Litewskiego. Dodanie do XV-wiecznego Prołogu żywotu św. Antoniego Supraskiego wskazuje na to, że postać męczennika wśród mnichów budziła powszechny szacunek. Świętego supraskiego dołączono do grona świętych z poprzednich stuleci, którzy w swych krajach obdarzeni byli powszechnym kultem. Autor ostatecznej wersji kodeksu pragnął nadać nowemu męczennikowi rangę równą świętym czeskim, serbskim czy moskiewskim ${ }^{107}$.

Język tekstu żywotu św. Antoniego wskazuje na to, że został on napisany przez mnicha z ziem ruskich, który nie posiadał dobrego kunsztu literackiego. Autor dodatku do Kodeksu znajdował się pod wpływem piśmiennictwa

nania dotyczace istoty ludzkiej. Podczas pobytu św. Sawy w celi w Karies miejsce to było nazywane „słup ortodoksji”. Trwała tu bez przerwy modlitwa oraz powstawały nowe hymny, pieśni i modlitwy ku chwale Boga w Trójcy Świętej. A. E. Tachiaos, Le monachisme serbe de Saint Sava et la tradition hésychaste athonite. „Hilandarski sbornik”, vol. I, Beograd 1966, s. 83-89; М. Живојиновиђ, Светогорске келије и пиргови у средњем веку, Београд 1972, с. 91-102; А. Е. Тахиос, Улога светога Саве у оквиру словенске књижевне делатности на Светој Гори, „Мећународни научни скуп Сава Немањић Свети Сава. Историја и предање. Децембар 1976", Београд 1979, с. 85-89.

105 Ten przywilej opierał się na sfałszowanym liście patriarchy Antoniego z 1392 r. i tomosie cesarza Manuela Paleologa z 1394 r. Oba dokumenty zostały potwierdzone w 1498 r. przez patriarchę Joachima i w ten sposób uzyskali swoją ważność. A. Фотиђ, Света Гора и Хиландар

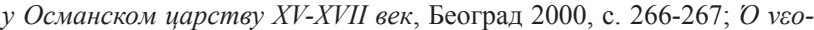

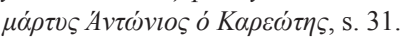

106 Odeska Biblioteka Narodowa w Odesie, sygn..4/119/, k. 367-374v; А. А. Турилов, Житие преподобномученика Антония Супрасльского и славянские жития балканских новомучеников XVI в. (к постановке проблемы), „Hagiographia Slavica”, ed. Herausg. von J. Reinhart, Munchen-Berlin-Wien 2013, (,Wiener Slawistischer Almanach. Sonderband". Bd. 82), s. 269-270. А. А. Турилов, Антоний Супрасльский, „Православная энциклопедия”, т. II, Москва 2001, с. 680; tenże, Житие преподобномученика Антония Супрасльского и славянские жития балканских новомучеников XVI в. (к постановке проблемы), „Hagiographia Slavica”, ed. Herausg. von J. Reinhart, Munchen-BerlinWien 2013, (,Wiener Slawistischer Almanach. Sonderband”. Bd. 82),

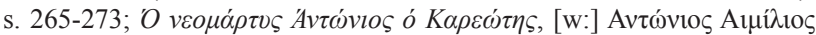

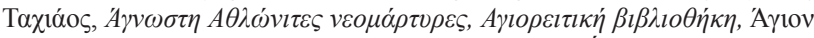
'Opos 2006, б. 11-49; Antoni i Marcin Mironowicz, Św. Antoni Supraski, Białystok 2014; A. Mironowicz, Święty Antoni Supraski, „Е $\Lambda \Pi І \Sigma ”$ Czasopismo Katedry Teologii Prawosławnej Uniwersytetu w Białymstoku, R. XVII (XXVIII), z. 29 (42), Białystok 2015, s. 11-24.

107 Biblioteka Litewskiej Akademii Nauk w Wilnie, Oddział Rękopisów, f. 19, nr 100. Por.: Rękopisy supraskie $w$ zbiorach krajowych $i$ obcych, opracował Antoni Mironowicz, Białystok 2014, s. 61-62; С. Ю. Темчин, Древнейшие рукописи Супрасльского Благовещенского монастыря (1500-1532 г2.): новые данныле, [в:] Современные проблемы археографии: сборник статей по материалам конференции проходившей в Библиотеке РАН, 25-27 мая 2010 г., Санкт-Петербург 2011, с. 134. 
serbskiego i bułgarskiego. Częste używanie samogłoski dźwięcznej и (ж) oznacza wyraźny wpływ języka bułgarskiego ${ }^{108}$. Na tej podstawie możemy stwierdzić, że pochodzący prawdopodobnie z Wołynia bądź Podlasia autor żywotu św. Antoniego Supraskiego albo przebywał na Świętej Górze Athos w bułgarskim monasterze ochrydzkim, albo oparł się na starszej bułgarskiej wersji zapisu hagiograficznego, która trafiła na ziemie ruskie. Występowanie rękopisów bułgarskich na terenie Wielkiego Księstwa Litewskiego w XV i XVI stuleciu było zjawiskiem dość częstym. Niestety, nie posiadamy żadnego dowodu na istnienie wcześniejszego serbskiego lub bułgarskiego oryginału żywotu świętego męczennika supraskiego. W tej sytuacji należy przyjąć, że jego anonimowy autor - Rusin sam przebywał w monasterze na Górze Athos, gdzie znajdowały się księgi napisane w języku bułgarskim i tam poznał losy Antoniego Supraskiego.

Prawdopodobnie twórcą żywotu św. Antoniego był wspomniany wyżej mnich supraski Arseniusz, który trafił do monasteru serbskiego w Chilandarze po $1536 \mathrm{r}$. W 1530 r. mnich supraski Arseniusz, były duchowny Aleksy, skopiował pracę św. Jana Klimaka Лествица. Книга Лествииа в полдесть znajdowała się $\mathrm{w}$ monasterze przed 1530 r. W wyniku powstałego konfliktu z archimandrytą Sergiuszem Kimbarem ${ }^{109}$, hieromnich Arseniusz zabrał skopiowaną przez siebie pracę św. Jana Klimaka Лествициa i udał się do serbskiego monasteru Chilandar na św. Górze Athos ${ }^{110}$. Arseniusz słysząc o męczeństwie schimnika An-

108 Е. Ф. Карский, Славянская кирилловская палеография, Ленинград 1928, c. $174-175$.

109 A. Mironowicz, Ewangelizacja ,,prosta mowa” w XVI wieku, „Latopisy Akademii Supraskiej”, vol. III, pod red. U. Pawluczuk, Białystok 2012, s. 9-18.

110 O supraskim pochodzeniu manuskryptu informuje nas zapis na jego 275 stronie. „В лето 7038 (1530), индикта 3, списана бысть книга Лествичникь у монастыри общомь в обители Благовещениа пресвятыя Богородица и святаго Иоанна Богослова иже на реци Супрасле, желаниемь и рукою многогрешнаго инока Арсениа, бывшаго вь мирском житии Алексеа недостоинаго попа". Katalog biblioteki rękopisów monasteru serbskiego Chilandar, nr 185; Д. Богданович, Каталог кирилских рукописа манастира Хиландара, Београд 1978, с. 104; Славянские рукописи Афонских обителей, составили: А. А. Турилов і Л. В. Мошкова, под редакцией А. Э. Н. Тахиоса, Фессалоники 1999, с. 127; Л. Л. Щавиская, Ю. А. Лабынцев, Литература белору- toniego mógł uwiecznić jego żywot i odesłać do monasteru supraskiego. I choć teza ta nie ma potwierdzenia źródłowego znajduje swoje uzasadnienie we wspólnym pochodzeniu obu mnichów, pobycie w tym samym serbskim klasztorze na Athosie oraz następstwie czasowym. Arseniusz trafił do Chilandaru w II połowie lat trzydziestych XVI wieku a żywot św. Antoniego powstał przed $1540 \mathrm{r}$. by zostać dołączonym do supraskiego „Prologu” w roku następnym.

Od połowy XVI wieku monaster supraski stał się głównym prawosławnym ośrodkiem zakonnym w Wielkim Księstwie Litewskim. Otwartość klasztoru na nowe trendy religijne i filozoficzne nie osłabiły jego pozycji w Kościele prawosławnym. Nadal utrzymywał on bliskie kontakty z tradycyjnymi ośrodków prawosławia w kraju i zagranicą min. $\mathrm{z}$ terenów Serbii i Bułgarii. Z monasterem supraskim powiązani byli wybitni działacze religijni z Księstwa Moskiewskiego, Bułgarii, Serbii i Bizancjum. Byli wśród nich O. Artemiusz, ks. Andrzej Kurbski, Maciej Czechowicz, Izajasz Kamienczanin, Ostafi Wołłowicz, Maciej Stryjkowski i patriarcha Serbski i Bułgarski Gabriel, który nadał archimandrycie Tymoteuszowi w 1582 roku prawo noszenia „mitry”"111. Do Ławry supraskiej przybył w 1589 roku powracający z Moskwy patriarcha carogrodzki Jeremiasz II ${ }^{112}$. Zreformował on zgromadzenie zakonne i uczynił z niego główną ostoję Cerkwi prawosławnej w zachodniej części Litwy. Pozycja klasztoru wpłynęła na wybór przez wielu dygnitarzy duchownych i świeckich miejsca swego wiecznego spoczynku ${ }^{113}$. Monaster dzięki kontaktom międzynarodowym zyskał miano ośrodka kulturalnego o ogólnosłowiańskim znaczeniu. W dziejach kultury dawnej Rzeczypospolitej monaster supraski stanowi doskonały przykład serbskiego oddziaływania kulturowego na ziemie białoruskie.

сов Польши XV-XIX вв., с. 61, 111, przyp. 36; Por.: Rękopisy supraskie w zbiorach krajowych i obcych, opracował Antoni Mironowicz, Białystok 2014, s. 73, 370-371.

111 АСД, т. IX, с. $82-83$

112 АСД, т. IX, с. 88

113 W krypcie cerkwi Zwiastowania NMP pochowano min. wojewodę smoleńskiego Bazylego Tyszkiewicza, ks. Katarzynę Chodkiewiczową i archimandrytę słuckiego Nikandera, $А С Д$, т. IX, c. 65, 73-74.

\section{Bibliografia}

\section{Źródla rękopiśmienne}

Библиотека Российской академии наук в Санкт-Петербурге, ф. П. Доброхотова, № 31, л. 41.

Российский Государственный Исторический Архив в Санкт-Петербурге, ф. 823, оп. 3, № 3317;

Российская государственная библиотека в Москве, Собрание Е. Е. Егорова, ф. 98, № 39;

Центральная научная библиотека Академии наук Украины в Киеве, 475п/1656, л. 1-21, 26об-96, 157-169, 198-201, 205-208;
Archiwum Diecezjalne Kościoła Rzymskokatolickiego w Białymstoku, nr. 245, k. 23v-24v, 26-60 v.

Archiwum Państwowe na Wawelu, Archiwum Młynowskie Chodkiewiczów, f. 36, nr. 29, k. 1, 80-84;

Biblioteka Muzeum Narodowego im. Czartoryskich w Krakowie, Zbiór dokumentów pergaminowych, nr. 66 (MNK $541 / 1)$

Biblioteka Narodowa w Warszawie, Biblioteka Ordynacji Zamojskich, Dział Rękopisów, нр. 930, к. 106-108 v.

Lietuvos Mokslų Akademijos Vrublevskių Biblioteka, ф. 19, нр.: $57,61,62,89,100,103,180,246,247$; 
Lietuvos Valstybes Istorijos Archyvas, ф. 634, оп. 1, нр. 58, к. 416 об; ф. 634, оп. 1, нр. 3, к. 14об-41об;

Vilniaus universiteto biblioteka, ф. F58-7, В 1993, к. 1-4 об; В 1994;

\section{Źródla drukowane}

Акты, издаваемые Виленской комиссией для разбора древних актов, т. VII, Вильна 1874, с. 3.

Акты исторические собранные и изданные Археографической комиссиею, т. I, Санкт-Петербург 1841, с. 524-529.

Археографический сборник документов, относящихся кистории Северо-Западной Руси, издаваемый при управлении Виленского учебного округа, т. IX, Вильно 1870, c. 49-55, 185-205, 229-243, 461-462;

Буланин Д. М., 2012, Чудо с грибом в Ксиропотаме, [в:] Словарь книжников и книжности Древней Руси. вып. 2: (Вторая половина XIV-XVI в.). ч. III: Библиографические дополнения. Приложение, ред. Д. М Буланин, Санкт-Петербург, с. 734-738;

„Вестник Западной России”, 1866, г. IV, кн. 7, т. III, отд. 1, Вильно, с. 2, 9-14;

„Вестник Западной России”, 1865/1866, г. IV, кн. 7, т. III, отд. 2, Вильно, с. 1-6;

„Вестник Западной России”, 1867, г. V, кн. 1, т. I, отд. 2, Вильно, Приложения, с. 1-3;

„Вестник Западной России”, 1867, г. V, кн. 7, т. I, отд. 2, Вильно, с. 1-3, 6-9, 11, 15, 71;

Древнерусские иноческие уставы, (Русский типик) подг. текста Т. В. Суздальцева, Москва 2001;

Попов А., 1879, Обличительные списания против жидов и латинян. (По рукописи имп. Публичной библиотеки 1580 2.), „Чтения в Императорском Обществе истории и древностей российских", Москва, кн. 1, с. 1-41;

Прадмова да Памянніка иі Сінодыка з Супрасльскага манаcmыра 1631 г., 2013 (опр. Л. В. Ляўшун), [в:] Рэлігійнае Пісьменства Кірылічнай Традыцыьі XI-XV cmст., Мінск, c. 547 ;

„Русская Историческая Библиотека”, 1878, т. IV, Памятники полемической литературы в Западной Руси, Кн. 1. Санкт-Петербург, с. 5-18;

„Русская историческая библиотека”, 1903, т. ХІХ, Памятники полемической литературы в Западной Руси. кн. III, Санкт-Петербург;

Славянские рукописи Афонских обителей, 1999, составили: А. А. Турилов і Л. В. Мошкова, под редакцией А. Э. Н. Тахиоса, Фессалоники, с. 127;

Супрасълски или Ретков сборник, 1982, Й. Заимов, увод и коментар на старобългарски текст, М. Капалдо, подбор и коментар на гръцкия текст, т. I, София;

Супрасълски или Ретков сборник, 1983, Й. Заимов, увод и коментар на старобългарски текст, М. Капалдо, подбор и коментар на гръцкия текст, т. II, София;

Супрасльская летопись, 1980, Полное собрание русских летописей, т. XXXV, Москва;

„Historica Russiae Monumenta”, 1841, ab A. I. Turgenevio, vol. 1, Petropoli, p. 123-127;

„Lietuvos Metrika”, 1995, (1499-1514), Knyga nr. 8, Vilnius, s. 143 .
Mironowicz A., 2015, Subotnik ili Pominnik monasteru supraskiego, Białystok, s. 10-12;

Mironowicz A., 2009, Summariusz dokumentów do dóbr supraskich, Białystok, s. 54-55, 57, 136, 139;

\section{Literatura}

Белецкий А., 1899, Митрополитъ Іосифь II Солтанъ и отношение его къ Супрасльскому монастырю, Вильна, с. 5-7, 12, 16-17, 19, 21-22, 34;

Богданович Д., 1978, Каталог кирилских рукописа манастира Хиландара, Београд, с. 104;

Бубнов И. Ю., Лихачева О. П., Покровская В. Ф., 1976, Пергаменные рукописи библиотеки Академии наук СССР, Леинград, с. 26;

Гильтебрандт П. А., 1871, Рукописное отделение Виленской публичной библиотеки, Вып.1, Вильна, с. 140.

Добрянский Ф. Н., 1882, Описание рукописей Виленской публичной библиотеки, иерковнославянских и русских, Вильна, с. XXVII-XXXIII, с. 68, 106-107, 117, 122-123, 224-227, 286;

Е. Н., [Епископ Никанор], 1904, Старый Синодик Супрасльского монастыря, „Гродненские Епархиальные Ведомости", № 27, с. 789;

Живојиновиђ М., 1972, Светогорске келије и пиргови у средюем веку, Београд, с. 91-102;

Зема В. Є., 2001, Полеміко-догматичні збірки XVI- початку XVII cm. „Українсьий історичний журнал”, нр. 5, с. 43$-74$

Иодковский И. И., 1915, Церкви приспособленные к обороне в Литве и Литовской Руси, „Древности”, т. VI, Москва c. 249-311;

Кацэр М. С., 1969, Белорусская архитектура, Минск, с. 48-52 ;

Корађ В., Ковачевиђ М., 2004, Монастир Хиландар. Конаци и утврђење, Београд, с. 58-62.

Лабынцев Ю. А., 2000, Об одном важном спросном моменте в судьбах белорусской православной культуры ХVI столетия в связи с историей Супрасльского Благовещенского

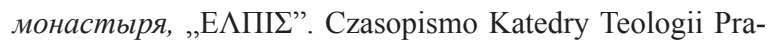
wosławnej Uniwersytetu w Białymstoku, R. II (XIII), z. 2 (15), Białystok, s. 168;

Макарий (Булгаков) Митрополит, 1879, История Русской Церкви, т. IX, Санкт-Петербург, с. 168;

Макарий (Булгаков) Митрополит, 1996, История Русской Церкви, кн. V, Москва, с. 168;

Манастир Хиландар, 2000, Београд, с. 14-15;

Миронович А., 2012, Библиотека Супрасльского монастыря в XVI веке, [в:] Преоткриване: Супрасльски сборник старобългарски паметник от Хвек, ред. А. Милтенова, София, с. 309-329;

Модест (Стрельбицкий), 1865/1866, Супрасльский Благовещенский монастырь, „Вестник Западной России. Историко-литературный журнал”, г. IV, кн. 7, т. III, отд. 2, Вильно, Приложения, № 1, с. 1-6, 9-14, 72;

Модест (Стрельбицкий), 1867, Супрасльский Благовещенский монастырь, „Вестник Западной России. Историко-литературный журнал”, . V, кн. 2, т. I, отд. 2, Вильно, c. $71-72$; 
Модест (Стрельбицкий), 1867, Супрасльский Благовещенский монастырь, „Вестник Западной России. Историко-литературный журнал”, г. V, кн. 6, т. II, отд. 2, Вильно, c. 128-131;

Модест (Стрельбицкий), 1867, Супрасльский Благовещенский монастырь, „Вестник Западной России. Историко-литературный журнал”, г. V, кн.7, т. II, отд. 2, 1867, c. 1-3, 6-9, 11-15, 71-73;

Модест (Стрельбицкий), 1865, Супрасльский Благовещенский монастырь, „Литовские Епархиальные Ведомости”, № 3, с. 75-76;

Монашество и монастыри в России XI-XX вв: исторические очерки, 2002, отв. ред. Н. В. Синицына, Москва;

Морозова Н. А., Темчин С. Ю., 1997, Об изучении иерковнославянской письменности Великого княжества Литовского, „Krakowsko-Wileńskie Studia Slawistyczne”, t. II, Kraków, s. 23-35;

Морозова Н. А., Темчин С. Ю., 2005, Древнейшие рукописи Супрасльского Благовещенского монастыря (1500-1532 2z.), [в:] Z dziejów monasteru supraskiego, Supraśl - Białystok, s. 131, 133-140;

Ненадовиђ С., 1997, Осам векова Хиландара. Грађење и грађевине, Београд, с. 21-23;

Николай (Далматов), 1892, Супрасльский Благовещенский монастырь, Санкт-Петербург, с. 6-7, 22, 24-27, 45, 62, 455-456, 464;

Обнорский С. П., 1914, К литературной истории Хождения Арсения Солунского, „Известия отделения русского языка и словесности Академии наук", т. ХІХ, кн. 3, с. 196-205.

Оболенский М. А., 1836, Супрасльская рукопись, содержащзая Новгородскую и Киевскую сокращенные летописи, Москва;

Петковић С., 1972, Нектарие Србин, сликар XV в., „Зборник за ликовне уметности", нр. VIII, Нови Сад с. 211-225;

Петковић С., 1995, Српска уметност у XVI и XVII веку, Београд, (Српска књижевна задруга. Коло 88, књ. 589), s. 255-281.

Петров Н. И., 1894, Западнорусские полемические сочинения $X V I$ века, „Труды Киевской Духовной Академии”, № 2, c. $154-186$.

Петров Н. И., 1894, Западнорусские полемические сочинения $X V I$ века, „Труды Киевской Духовной Академии”, № 3, c. 349-380.

Петров Н. И., 1895, Супрасльский монастырь как защитник православия в XVI и в начале XVII века, „Виленский календарь на 1896 год”, Вильно, с. 164-179;

Петрушевич А., 1867, Холмская епархия и святители ее, Львов, с. 32;

Покровский Ф., 1895, Археологическая карта Гроденской губерни, Вильна, с. 72;

Покровский Ф., 1908, Послание Василия, пресвитера Никольского из дольней Руси об исхождении Святого Духа, «Известия Отделения русского языка и словесности”, т. CXII, кн. 3, прл. 1, с. 86.,

Покрышкин П. П., 1911, Благовещенская церковь в Суnрасльском монастыре, [в:] Сборник археографических статей поднесеный графу А. А. Бобринскому, Санкт-Петербург, с. 222-237;
Рогов А. И., 1980, Фрески Супрасля, [в:] Древнерусское искусство. Монументальная живопись XI-XVII вв., Москва, с. 345-371;

Рогов А. И., 1978, Литературные связи Белоруссии с балканскими странами в XV-XVI вв., [в:] Славянские литератуpы. VIII Международный съезд славистов, Загреб-Любляна, сентябрь 1978 г. Докладь советской делегации, Москва, с. 187-194;

Рогов А. И., 1978, Супрасль как один из цеентров культурных связей Белоруссии с другими славянскими странами, [в:] Славяне в эпоху феодализма, Москва, с. 330-331;

Рогов, А. И., 1980, „Фрески Супрасля“, Подобедова, О. И. (отв. ред.), Древнерусское искусство. Монументальная живопись XI - XVII вв., Москва, 343-356;

Тахиаос А. Е., 1979, Улога светога Саве у оквиру словенске къижевне делатности на Светој Гори, „Мећународни научни скуп Сава Немањић Свети Сава. Историја и предање. Децембар 1976", Београд, с. 85-89;

Темчин С. Ю., 2014, Афоно-сербский оригинал супрасльского рукописного комплекта служебных миней серединь $X V I$ в. и его дальнейшая судьба, „Афон и славянский мир. Сборник”, нр. 1, ред. Ж. Л Левшина, Афон, с. 184-192 ;

Темчин С. Ю., 2011, Древнейшие рукописи Супрасльского Благовещенского монастыря (1500-1532 г2.): новые данные, [в:] Современные проблемы археографии: сборник статей по материалам конференции проходившей в Библиотеке РАН, 25-27 мая 2010 г., Беляева И. М. (ред.), Санкт-Петербург, с. 134;

Темчин С. Ю., 2011, Послесловие к четьему „Апостолу” 1183 года монаха Исайи в супрасльскогм списке Матвея Десятого 1502-1507 года, „Krakowsko-Wileńskie Studia Slawistyczne", t. VI, Kraków, s. 131;

Темчин С. Ю., 2010, Рукописи Кимбаровского собрания Супрасльского Благовещенского монастыря (1532-1557 г2.), „Knygotyra”, t. LIV, Vilnius, c. 173-180;

Темчин С. Ю., 2010, Сколько книг было в Супрасльском Благовещенском монастыре, [в:] „Здабыткі: Дакументальныя помнікі на Беларусі”, вып. 12, Мінск, с. 70-75;

Темчин С. Ю., 2007, Супрасльский список хроники Георгия Амартола середины ХVI века и его антиграф 1494 года, „Knygotyra”, vol. 49, c. 77;

Темчин С. Ю., 2012, О хиландарском проишождении афонско-сербского оригинала супрасльских рукописных

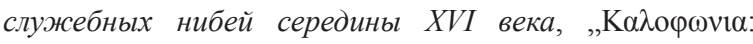
Науковий збірник з історії церковної монодії та гимнографії”, ч. VI, Львів, с. 15-20;

Турилов, А. А. 2001, „Антоний Супрасльский”, Православная энциклопедия, т. II, Москва, с. 680;

Турилов, А. А. 2001, „Южнославянские памятники в литературе и книжности Литовской и Московской Руси XV - первой половины XVI в. - парадоксы истории и географии культурных связей”, Славянский альманах 2000, Москва, 247-285.

Турилов А. А., 2013, Житие преподобномученика Антония Супрасльского и славянские жития балканских новомучеников XVI в. (к постановке проблемы), „Hagiographia Slavica”, ed. Herausg. von J. Reinhart, Munchen-Berlin- 
Wien, (,Wiener Slawistischer Almanach. Sonderband”. Bd. 82), s. 265-273;

Улащик Н. Н., 1985, Введение в изучение белорусско-литовского летописания, Москва, с. 35;

Ульяновський В. І., 1994, Історія церкви та релігійної думки в Україні у трьох книгах. Кн.1: Середина XV-кінеи XVI століття, Київ, с. 103;

Фотиђ А., 2000, Света Гора и Хиландар у Османском ияарству XV-XVII век, Београд, с. 266-267;

Церетели Е., 1899, Елена Иоанновна, великая княгиня литовская, русская, королева польская, Санкт-Петербург, с. 242 ;

Чантурия В. А., 1969, История архитектуры Белоруссии, Минск, с. 88-90;

Чистякова, М. В. 2011. „Текстологические особенности стишного пролога ГИМ, Увар. 56“, Slavistica Vilnensis 2010 (Kalbotyra 55 (2)), c. 46-62.

Щавиская Л. Л., 1998, Литературная культура белорусов Подляшья XV-XIX вв., Книжные собрания Супрасльского Благовещенского монастыря, Минск, с. 38;

Щавиская Л. Л., Лабынцев Ю. А., 2003, Литература белорусов Польши XV-XIX вв., Минск, с. 61-71, 111;

Alexandrowicz S., 1971, Nowe źródło ikonograficzne do oblężenia Polocka w 1579 r., „Kwartalnik Historii Kultury Materialnej”, R. XIX, z. 1, Warszawa, s. 19-22;

Grala H., 1997, Kotpak Witołdowy czy czapka Monomacha? (Dylematy wyznawców prawosławia w monarchii ostatnich Jagiellonów), [w:] Katolicyzm w Rosji i prawosławie w Polsce (XI-XXw.), Warszawa, przyp. 3, s. 61;

Jasnowski J., 1937, Chodkiewicz Aleksander, „Polski Słownik Biograficzny", t. III, Kraków, s. 354;

Kierejczuk E., 2011, Kodeks supraski wśród zbiorów biblioteki monasteru supraskiego. Kilka hipotez w sprawie czasu przybycia Minieji Czetnej z XI wieku do Supraśla, „Latopisy Akademii Supraskiej”, pod red. U. Pawluczuk, vol. II, Białystok, s. 141-150;

Kochanowski W., 1963, Pobazyliański zespót architektoniczny w Supraślu, ,Rocznik Białostocki”, nr 4, Białystok, s. 355-396.

Lebiedzińska Z., 1968, Freski z Supraśla. Katalog wystawowy, Kraków, s. 26;

Luba-Radzimiński Z., 1928, Sprawa odrębnego pochodzenia Chodkiewiczów litewskich i białoruskich, „Rocznik Polskiego Towarzystwa Heraldycznego", t. VIII, R. 1926-1927, Kraków, s. 109-132;

Maroszek J., 2013, Monografia miasta i gminy Supraśl, Supraśl, s. 429-564;

Mironowicz A., 2011, Biblioteka monasteru supraskiego w XVI wieku, „Białoruskie Zeszyty Historyczne”, nr 36, Białystok, s. 5-23;

Mironowicz A., 2015, Biblioteka monasteru supraskiego do połowy XVI wieku, Матэрялы XI Міжнародных кнігазнаўчых чытанняў „Кніжная культура Беларусі XI - пачатку XX ст.", Мінск, 16-17 красавіка 2015 г., Мінск, с. 64-75.

Mironowicz A., 2012, Ewangelizacja „prosta mowa” w XVI wieku, „Latopisy Akademii Supraskiej”, vol. III, pod red. U. Pawluczuk, Białystok, s. 9-18.

Mironowicz A., 1988, Kodeks supraski, „Białostocczyzna”, nr 1(9);
Mironowicz A., 2003, Kościót prawosławny w państwie Piastów i Jagiellonów, Białystok, s. 223, 225;

Mironowicz A., 1988, Latopisy supraskie jako jedno ze źródet „Kroniki polskiej...” Macieja Stryjkowskiego, [w:] Studia polsko-litewsko-białoruskie, Prace Białostockiego Towarzystwa Naukowego, nr 31, pod red. J. Tomaszewskiego, E. Smułkowej i H. Majeckiego, Warszawa, s. 22-32;

Mironowicz A., 2011, Literatura bizantyjska w Kościele prawostawnym na terenie Wielkiego Księstwa Litewskiego w XVI wieku, „Търновска Книжовна Школа”, Търново и идеята за Християнския Универсализъм XII-XV век, т. IX, Велико Търново, с. 692-704;

Mironowicz A., 2009, Literatura bizantyjska $w$ Kościele prawostawnym na terenie Wielkiego Księstwa Litewskiego w XVI Literatura bizantyjska w Kościele prawosławnym na terenie Wielkiego Księstwa Litewskiego w XVI wieku, „Białoruskie Zeszyty Historyczne", nr 31, Białystok, s. 145-147;

Mironowicz A., 2015, Rękopisy butgarskie $w$ zbiorach biblioteki monasteru supraskiej do połowy XVI wieku, „Търновска книжовна школа”, нр. 10, „Търновска Държава на духа”, Велико Търново, с. 17-39;

Mironowicz A., 2013, Najstarszy Субботник или Поминник monasteru supraskiego, „Białoruskie Zeszyty Historyczne”, nr 40, Białystok, s. 233-243;

Mironowicz A., 2003, Największa fundacja Aleksandra Chodkiewicza. Spór o charakter fundacji, [w:] Władza i prestiz. Magnateria Rzeczypospolitej w XVI-XVIII wieku, pod red. J. Urwanowicza, Białystok, s. 529-550;

Mironowicz A., 2015, Nieznane losy pierwszych ihumenów supraskich, Białystok, s. 41-59, 84-98;

Mironowicz A., 2013, O początkach monasteru supraskiego i jego fundatorach, Supraśl, s. 12-18, 34-35;

Mironowicz A., 2014, Sobory wileńskie 1509 i 1514 roku, [w:] Synody Cerkwi prawosławnej w I Rzeczypospolitej, pod red. Marzanny Kuczyńskiej i Urszuli Pawluczuk, „Latopisy Akademii Supraskiej”, vol. 5, Białystok 2014, s. 71-82.

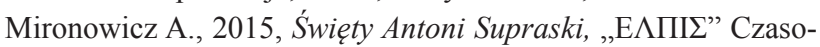
pismo Katedry Teologii Prawosławnej Uniwersytetu w Białymstoku, R. XVII (XXVIII), z. 29 (42), Białystok, s. 11-24;

Mironowicz A., 1989, Zwiąki literackie Kijowa z monasterem supraskim w XVI wieku, „Slavia Orientalis”, t. XXXVIII, nr 3-4 s. 541-542;

Mironowicz A., 2009, Związki monasteru supraskiego ze Święta Góra Athos w XVI wieku, [w:] Święta Góra Athos w kulturze Europy. Europa w kulturze Athos, pod red. M. Kuczyńskiej, Gniezno, s. 122-134;

Mironowicz A., 1998, Życie monastyczne na Podlasiu, Białystok, s. 14-17;

Mironowicz A. i M., 2014, Św. Antoni Supraski, Białystok;

Morelowski M., 1939, Zarys syntetyczny sztuki wileńskiej od gotyku do neoklasycyzmu z przewodnikiem po zabytkach między Niemnem a Dźwina, Wilno;

Naumow A., 2005, Monaster supraski jako jeden z głównych ośrodków kulturalnych w Rzeczypospolitej, [w:] Z dziejów monasteru supraskiego, Supraśl-Białystok, s. 108, 110;

Papée E., 1949, Aleksander Jagiellończyk, Kraków, s. 71-72.

Rękopisy supraskie $w$ zbiorach krajowych i obcych, 2014, pod red. A. Mironowicz, Białystok, s. 11-50, 61-62; 
Siemaszko A., 2006, Freski z Supraśla: unikatowy zabytek XVI -wiecznego pobizantyńskiego malarstwa ściennego, Białystok, s. 38-48.

Siemaszko A., 1996, Malowidta ścienne cerkwi Zwiastowania $w$ Supraślu. Rekonstrukcja programu ikonograficznego, „Zeszyty Naukowe Uniwersytetu Jagiellońskiego. Prace z historii sztuki", z. 21, Kraków, s. 13-58;

Stawicki St., 1972 Czy Nektarij autor , Typika” byt autorem malowidet supraskich? „Biuletyn Historii Sztuki”, R. XXXIV, nr 1, Warszawa, s. 30-35;

Szymański S., 1972, Freski z Supraśla. Próba rekonstruowania genealogii, „Rocznik Białostocki”, t. XI, Białystok, s. 161$-181$

Szyszko-Bogusz A., 1914, Warowne zabytki architektury kościelnej w Polsce i na Litwie, [w:] Sprawozdanie Komisji do badań nad historia sztuki w Polsce, т. IX, z. 3-4, Kraków;

Tachiaos A. E., 1966, Le monachisme serbe de Saint Sava et la tradition hésychaste athonite. „Hilandarski sbornik”, vol. I, Beograd, p. 83-89;
Takala-Roszczenko M., 2013, The 'Latin' within the 'Greek': The Feast of the Holy Eucharist in the Context of Ruthenian Eastern Rite Liturgical Evolution in the 16th-18th Centuries, Joensuu, p. 69-71;

Trajdos T. M., 1985, Metropolici Kijowscy Cyprian i Grzegorz Camblak a problemy Cerkwi prawosławnej w państwie polsko-litewskim u schyłku XIV $i$ w pierwszej ćwierci XV w., „Balcanica Posnaniensia. Acta et studia”, t. II, Poznań, s. 211-234;

Wolff J., 1895, Kniaziowie litewsko-ruscy od końca czternastego wieku, Warszawa, s. 618;

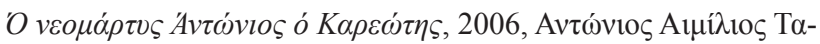

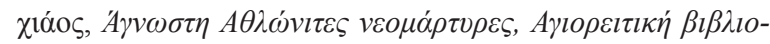

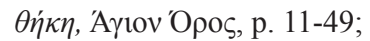

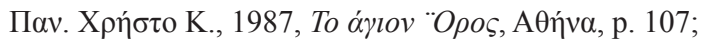

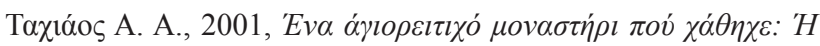

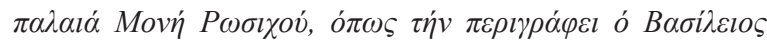

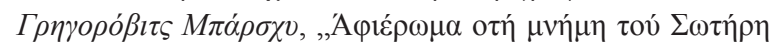

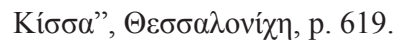

Rozmiar artykułu: 2 arkusze wydawnicze 
ISSN 1508-7719

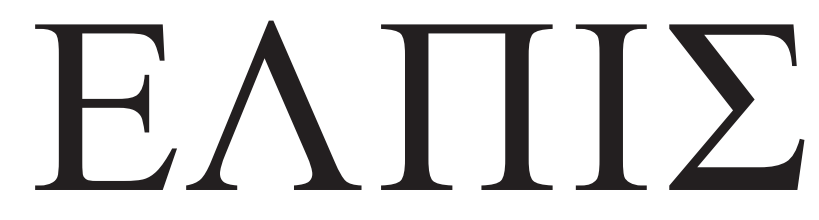

CZASOPISMO TEOLOGICZNE KATEDRY TEOLOGII PRAWOSŁAWNEJ UNIWERSYTETU W BIAŁYMSTOKU

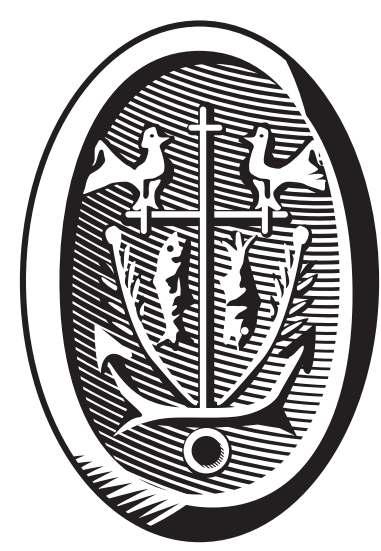

ADRES REDAKCJI

15-097 Białystok, ul. M. Skłodowskiej-Curie 14 tel. 85 745-77-80, e-mail: redakcja@elpis.edu.pl www.elpis.uwb.edu.pl 